\title{
REVIEW
}

\section{Paroxysmal nocturnal haemoglobinuria: Nature's gene therapy?}

\section{R J Johnson, P Hillmen}

J Clin Pathol: Mol Pathol 2002;55:145-152

The development of paroxysmal nocturnal haemoglobinuria (PNH) requires two coincident factors: somatic mutation of the PIG-A gene in one or more haemopoietic stem cells and an abnormal, hypoplastic bone marrow environment. When both of these conditions are met, the fledgling PNH clone may flourish. This review will discuss the pathophysiology of this disease, which has recently been elucidated in some detail.

See end of article for authors' affiliations

$\ldots \ldots \ldots \ldots \ldots \ldots$

Correspondence to: Dr R J Johnson, Birmingham Heartlands Hospital, Bordesley Green East, Birmingham B9 5SS, UK; johnsonr@ heartsol.wmids.nhs.uk

Accepted for publication 24 January 2002
$\mathrm{T}$ he development of paroxysmal nocturnal haemoglobinuria $(\mathrm{PNH})$ requires two coincident factors: somatic mutation of the PIG-A gene in one or more haemopoietic stem cells and an abnormal, hypoplastic bone marrow environment. When both of these conditions are met, the PNH clone may flourish. Recently, the pathophysiology of this disease has been elucidated in some detail and we now have rational theories concerning the clinical manifestations of PNH, its association with other haematological disorders (such as aplasia and myelodysplasia), and the sequence of events that leads to overt disease. Spontaneous somatic mutations are common in the PIG-A gene, leading to failure of synthesis of the glycosyl phosphatidylinositol (GPI) anchor. Without this structure, many proteins are unable to attach to cell surfaces. Red blood cells lose complement defence proteins, which explains the classic feature of intravascular complement mediated haemolysis. There is indirect evidence that platelet activation with consequent thrombosis is caused by a similar mechanism. The relative growth advantage of PNH cells in a hypoplastic marrow is also, presumably, a direct or indirect result of these alterations in surface antigen composition, although the precise pathophysiological mechanisms remain to be described. It is probable that the association with aplasia is explained by this relative growth advantage and that clonal evolution to a leukaemic state is a consequence of the primary insult causing the aplasia. In this way, PNH can be seen as an attempt to restore a form of useful, if abnormal, haemopoiesis in a damaged bone marrow: nature's gene therapy.

\section{THE EVOLUTION OF OUR} UNDERSTANDING OF PNH

$\mathrm{PNH}$ as a clinical entity has puzzled physicians and scientists for 200 years. Perhaps the first description was "An account of a singular periodic discharge of blood from the urethra" written in 1794 by a Scottish surgeon, Charles Stewart. However, the first detailed description is credited to Paul Strübing in $1882 .{ }^{1}$ His patient had a six year history of passing dark urine intermittently in the mornings, always clearing by noon. His conclusions were detailed and astonishingly perceptive, suggesting as he did that there was intravascular haemolysis and that some of the patient's symptoms were the result of thrombosis. He even concluded (correctly) that a red blood cell defect was to blame. Despite this insight, the work was largely ignored and when Marchiafava reported a case in Italy 29 years later it was regarded as a new entity. ${ }^{2}$ Michelli published further observations in 1931 and used the weighty term "splenomegalic haemolytic anaemia with haemoglobinuria and haemosiderinuria, Marchiafava-Michelli type" from which the disease retains the eponym. ${ }^{3}$ The modern term PNH was first coined shortly before Michelli's paper in a description of a case from the Netherlands. ${ }^{4}$

Attempts to explain the haemolysis began in Rotterdam in 1911, when Hÿmans van den Bergh noted that $\mathrm{PNH}$ erythrocytes were sensitive to lysis in vitro when exposed to carbon dioxide. ${ }^{5}$ By the 1930s it had been shown that the lysis was complement mediated and pH dependent: being greatest in acidified conditions. ${ }^{6}$ This formed the basis for Ham's test, ${ }^{7}$ which was the diagnostic gold standard until its replacement by flow cytometry in recent years.

In 1944, Sir John Dacie first noted the association of PNH with aplasia in a case of Fanconi's anaemia. ${ }^{8}$ In the 1950s, the defect was shown to be present in other haemopoietic lineages, with the observation that the neutrophil alkaline phosphatase was reduced or absent in PNH. This led Dacie to suggest that PNH was an acquired clonal disorder arising in a haemopoietic stem cell. ${ }^{10}$ This important and perceptive idea was later confirmed by an elegant report in two patients with $\mathrm{PNH}$ who were also heterozygous for the enzyme glucose-6-phosphate dehydrogenase. ${ }^{11}$ In this study, it was shown that the patients' red cells with a PNH phenotype contained only one isotype of glucose-6-phosphate dehydrogenase whereas their residual, non-PNH cells contained both.

Abbreviations: $A A$ aplastic anaemia: $E R$ endoplasmic reticulum; GPI, glycosyl phosphatidylinositol; GlcNAc, $\mathrm{N}$-acetylglucosamine; PEA, phosphoethanolamine; PI, phosphatidylinositol; $\mathrm{PNH}$, paroxysmal nocturnal haemoglobinuria; VSG, variant surface glycoprotein 

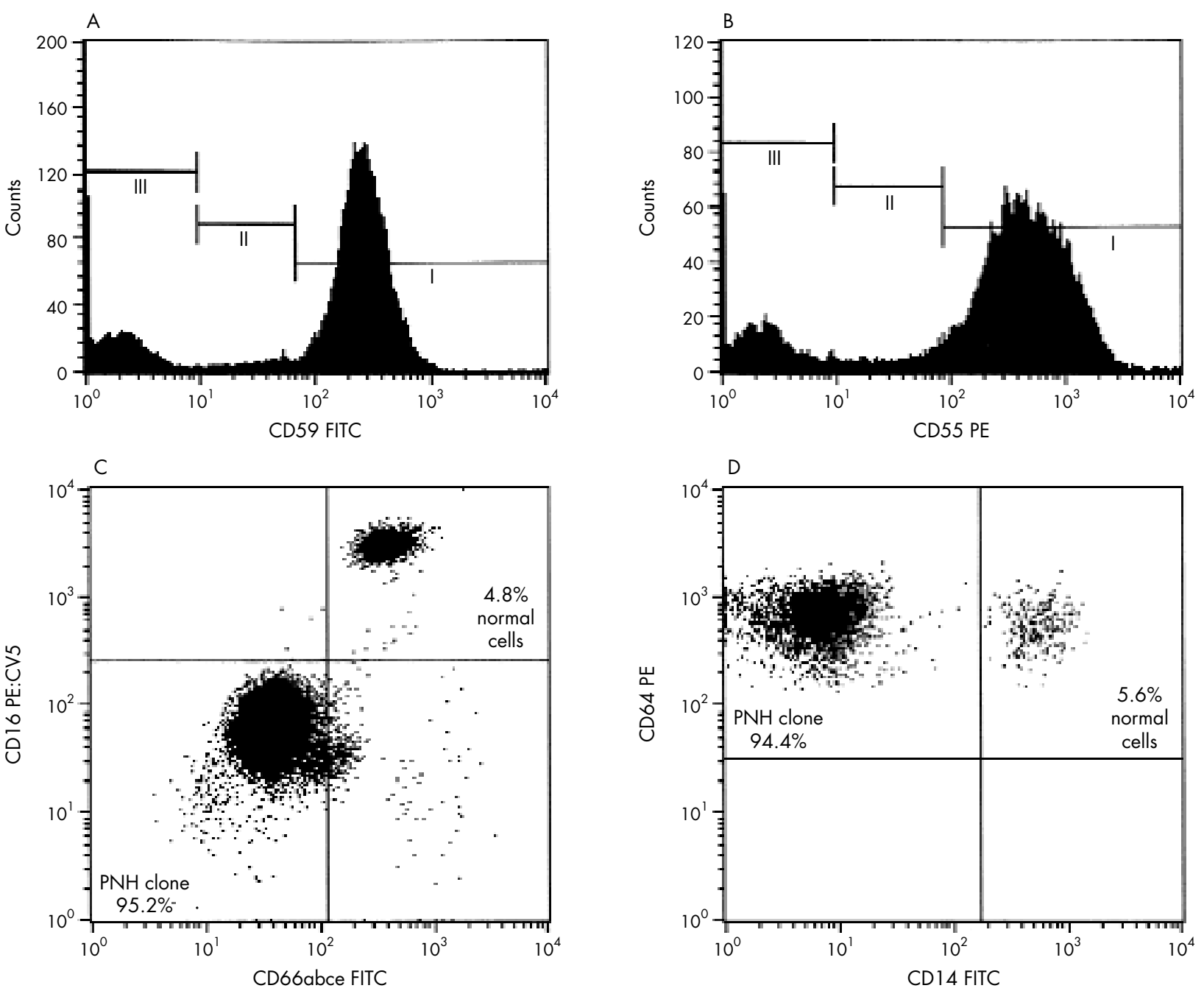

Figure 1 An example of peripheral blood phenotyping in paroxysmal nocturnal haemoglobinuria (PNH). Plots from a flow cytometer showing the clear discrimination between populations of normal and PNH cells in a patient's peripheral blood sample. $(A, B)$ Plots showing the three types of red blood cells that can be detected in these patients. Type 1 cells are normal, type II are partially deficient in glycosyl

phosphatidylinositol (GPI) linked proteins, and type III are wholly deficient. CD55 and CD59 are GPI linked antigens found on red blood cells. (C) Plot showing granulocytes that have been dual stained with two GPI linked surface antigens (CD16 and CD66) in a patient with PNH. This clearly delineates the normal and the PNH cells. (D) Plot using the same double staining method but with antigens relevant to monocytes (CD64 and CD 14): the same clear demarcation is shown. Courtesy of Dr S Richards, Haematological Malignancy Diagnostic Service, The General Infirmary, Leeds, UK.

"Ham's test was the diagnostic gold standard until its replacement by flow cytometry in recent years"

From the 1960s onwards, an increasing number of proteins were shown to be missing from the cell surface in PNH. These included molecules known to be involved in the regulation of complement at cell surfaces. It was hypothesised that their absence caused a complement mediated intravascular haemolysis. Decay accelerating factor (DAF/CD55), which has a role in the inactivation of complement at an early stage of the cascade, was thought to be important but individuals with the Inab red cell phenotype, who have an inherited DAF deficiency, had no clinical illness or in vitro red cell complement sensitivity. ${ }^{12}$ CD59, which inhibits the formation of the membrane attack complex (the final step in the complement cascade) was the next candidate. Clinical evidence for the importance of this molecule came in 1992 when a 22 year old man was described who had a homozygous deficiency of CD59 on all his cells and suffered PNH-like symptoms, with haemolysis and cerebral thrombosis. ${ }^{13}$ It is probable that the haemolytic and thrombotic features of PNH are mediated by complement sensitivity and that CD59 deficiency is an important cause of this.
The biochemical explanation for the absence of these proteins became clear when the GPI anchor was described as a novel mechanism of attachment of antigens to cells in $1980 .{ }^{14}$ It was subsequently shown that all the proteins absent in PNH were GPI linked and that all GPI linked antigens are missing from PNH cells. In the past decade, the structure and biochemistry of the GPI anchor have been described and there is a consistent biosynthetic abnormality in all patients with PNH described to date. ${ }^{15}$

A gene whose cDNA is able to correct this defect in all transfected human cell lines has now been cloned..$^{16}$ It is situated on the short arm of the X chromosome and has been named PIG-A, a term derived from its ability to restore the GPI synthetic defect in class A murine cell lines. ${ }^{17}$ Since the gene has been cloned, mutations have been found in all patient samples reported. ${ }^{18}$

This sequence of historical milestones has taken PNH from its most obvious clinical manifestation right back to a single gene defect in a haemopoietic stem cell. The story is in one sense complete but there are still many intriguing questions to be answered. 


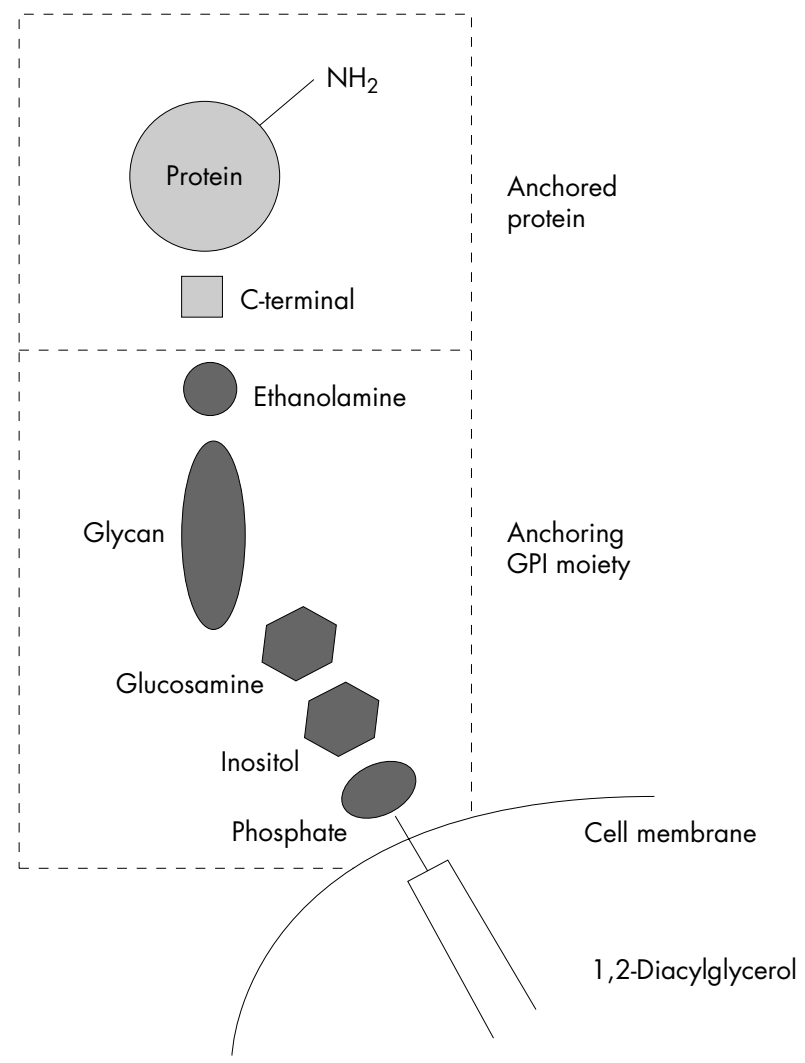

Figure 2 The glycosyl phosphatidylinositol (GPI) anchor. This is a simplified diagram of the GPI structure. The C-terminus of the anchored protein links to an ethanolamine residue on the GPI anchor. The anchor itself consists of this ethanolamine moiety attached to a glycan core. The GPI structure attaches to the cell membrane via phosphatidylinositol. The glycan core consists of a molecule of GlcNAc linked to three mannose residues. The first step in GPI synthesis is the linkage of the GlcNAc to PI. It is this reaction that fails in paroxysmal nocturnal haemoglobinuria because the genetic lesion disrupts the production of a necessary enzyme complex.

\section{CLINICAL ASPECTS OF PNH Epidemiology}

PNH is a rare disease. One of the largest epidemiological studies looked back at data from French centres from 1946 to 1995 and found only 220 reported cases. ${ }^{19}$ The annual incidence is about 4/million and the overall frequency is probably similar to that of aplastic anaemia (AA) with which it has a close association. It is probable that greater awareness and improved diagnostic methods will increase the number of diagnosed cases. The UK PNH registry in Leeds has been collecting new and existing cases since 1990 and currently has over 140 recorded patients ( $\mathrm{P}$ Hillmen, personal observation, 2001).

\section{Clinical features}

Patients with PNH may have a long term chronic illness but the disease does shorten life. The median survival from diagnosis was 10 to 15 years in two large historical studies. ${ }^{19} 20$ Patients most commonly die of thrombosis or progressive cytopenias. Leukaemic transformation is uncommon $(<5 \%)$. Many patients will continue to have intermittent paroxysms of haemolysis but some eventually achieve a spontaneous remission. ${ }^{20}$ The identification of patients destined to remit is clearly an important requirement to prevent the use of toxic treatments in patients with a good prognosis.

Haemolysis is the cardinal feature. It is classically paroxysmal and most apparent in the first urine passed on wakinghence the name of the disease. In practice, patients often have a chronic haemolysis with exacerbations. This results in a variable transfusion requirement with iron deficiency often contributing to the anaemia. All patients should receive daily folic acid, because a low degree of haemolysis is usual between paroxysms. Heavily transfused patients can, paradoxically, become iron overloaded and this should be monitored to avoid compounding the problem with iron supplements.

Thrombosis is the most feared complication. There is a well established predilection for the hepatic veins but a diversity of predominantly venous sites has been described. Patients with AA and only laboratory evidence of PNH are much less likely to suffer a thrombosis than those with active haemolysis and a large proportion of $\mathrm{PNH}$ cells in their blood. In this last group, thrombosis may occur in up to $50 \%$ and be the cause of death in one third. ${ }^{19} 20$

The intimate connection between AA and PNH is underlined by the clinical course of the illness in individual patients. Some degree of cytopenia is a consistent finding, even in haemolytic PNH. This may range from a mild reduction in one cell lineage to life threatening bone marrow failure. Even when blood counts are normal, bone marrow examination and progenitor culture assays reveal impaired haemopoiesis.

Malignancy, such as myelodysplasia or acute myeloid leukaemia supervenes in around 5\% of cases, but is probably a result of the process leading to AA rather than a specific risk related to the PNH clone itself, which is not considered preleukaemic. ${ }^{21}{ }^{22}$

\section{Diagnosis}

The demonstration of non-immune haemolysis with haemosiderinuria should lead to an investigation for PNH. Alternatively, its presence may be sought because of AA or a venous thrombosis at an unusual anatomical site. The diagnosis is definitively established by the demonstration of GPI linked protein deficiencies on red blood cell and neutrophil surfaces by multiparameter flow cytometry. ${ }^{23}$ The Ham test has been largely abandoned where flow cytometry is available, because it is relatively insensitive and labour intensive and only gives information on red blood cells. The solid phase gel techniques used for antibody detection in blood transfusion provide a rapid screen but again are limited to red blood cell antigens. The proportion of affected red blood cells often gives a falsely low assessment of the true clone size because of the effects of the selective haemolysis of PNH red cells compared with their normal counterparts and because of the effect of transfusion. The neutrophil series is not affected by these variables and therefore allows an accurate measurement of the clone size. It is possible to detect $\mathrm{PNH}$ clones that comprise $<1 \%$ of neutrophils using multiparameter flow cytometry. ${ }^{24}$ It is important to include a transmembrane antigen as a lineage marker (for example, CD15 for neutrophils) and at least two GPI linked antigens (for example, CD55 and CD59) to exclude the rare inherited deficiencies of single antigens such as the Inab phenotype (CD55 deficiency).

"It is probable that the haemolytic and thrombotic features of paroxysmal nocturnal haemoglobinuria are mediated by complement sensitivity and that CD59 deficiency is an important cause of this"

Using flow cytometry, it is possible to demonstrate patterns of complete or partial GPI linked protein deficiency on the red blood cell series. Normal cells are designated type I, partially deficient type II, and completely deficient type III (fig l). The clinical severity of the disease is directly related to the proportion of type III red blood cells.

If these techniques are applied to other haemopoietic cell lineages, GPI deficiency can be documented on platelets, monocytes, and lymphocytes, confirming the stem cell nature of the disorder ${ }^{25}$ ( fig l). 


\section{Treatment}

This is another area much influenced by the interplay of PNH and AA. Those with AA or progressive pancytopenia may be candidates for intensive disease modifying treatment, including immunosuppression or bone marrow transplantation. These approaches are usually not appropriate for classic PNH without bone marrow failure. Interesting exceptions to this rule are disease occurring in patients with a syngeneic twin. In this circumstance, there is little risk from transplant, although it appears that at least moderate doses of conditioning chemotherapy before stem cell infusion are necessary to prevent re-expansion of the PNH clone. ${ }^{26}$

Most patients without pronounced cytopenias simply require supportive management. Blood transfusion is the mainstay for those with symptomatic anaemia. Folate supplementation is mandatory and iron status should be monitored because patients can become iron deficient through urinary loss or iron overloaded from blood. Because thrombosis is a leading cause of mortality in this group, all those with haemolytic disease or a large percentage of PNH cells in their blood (perhaps $>50 \%$ PNH neutrophils) should be considered for primary prophylaxis with warfarin if there are no contraindications. ${ }^{20}$

\section{THE BIOCHEMICAL AND MOLECULAR BASIS OF PNH}

A failure of GPI anchor synthesis is a constant and key feature in all cases of PNH. The genetic basis of this abnormality is now well described, as is the detail of the biochemical consequences. ${ }^{16}{ }^{18}{ }^{27}$ GPI deficiency causes a loss of many proteins from the cell surface. The resulting cell phenotype explains the clinical features and suggests a mechanism for expansion of the PNH clone. These assumptions, while reasonable, await further experimental proof and the correlation of all clinical sequelae with specific protein loss has yet to be achieved. Before speculating on this, it is worth describing what we know about the GPI anchor, the missing proteins, and the underlying genetic defect.

\section{The GPI anchor}

Most cell surface proteins are attached via a sequence of hydrophobic amino acids that spans the lipid portion of the bilayer. This transmembrane domain achieves a stable interaction, which is not easily disrupted without destroying the membrane itself. In the 1980s, another method of cellular attachment was described whereby proteins were linked to a GPI molecule, which was itself inserted into the cell membrane. ${ }^{28}$ The structure and the biosynthesis of this GPI anchor were determined from work in trypanosomes, whose major surface glycoprotein is attached by this mechanism. ${ }^{29}$ The backbone of the GPI structure is highly conserved between species.

There are essentially three parts to the GPI anchor (fig 2). The membrane attachment is achieved through the insertion of the lipid moiety of phosphatidylinositol (PI) into the outer leaflet of the membrane. There is then a glycan core consisting of a molecule of $\mathrm{N}$-acetylglucosamine (GlcNAc) linked to three mannose residues and then to an ethanolamine. The protein attachment site is to the phosphoethanolamine (PEA) molecule linked to the terminal mannose. The C-terminus of the relevant protein is linked to the amino group of the PEA molecule by an amide bond..$^{18} 3031$

\section{"Glycosyl phosphatidylinositol deficiency causes a loss of many proteins from the cell surface"}

Biosynthesis of the GPI moiety occurs in the rough endoplasmic reticulum (ER). The precise location at which each reaction takes place is still a matter of some doubt. Some of the steps take place on the cytoplasmic surface of the ER and some within the cisternal space. ${ }^{32}$ The first step in the process is the addition of a molecule of GlcNAc to a PI residue. This does take place on the cytoplasmic surface of the ER and, at some point, the developing molecule is flipped to the cisterna. A series of three mannosylations follows using dolichol-phosphate mannose as a donor. Ethanolamine is added to each of these sugars. Transamidation of the newly synthesised protein leads to its attachment to the PEA molecule on the terminal mannose and finally the proteinGPI complex is transported to the external surface of the cell.

\section{The importance of GPI linkage}

The high degree of interspecies conservation of the GPI structure and its wide distribution argues for an important biological role for this mechanism of protein attachment. Most available information comes from work on trypanosomes and animal studies and the relevance to humans is speculative.

Enzymes have been characterised that cleave GPI anchors, thus releasing the tethered proteins. ${ }^{33}$ These phospholipases are present in other mammals and trypanosomes and their existence suggests that some proteins may be anchored through GPI to allow their selective removal. An example of this is the deliberate cleavage of the major surface protein (variant surface glycoprotein; VSG) of the trypanosome and its replacement with an immunologically discrete variant VSG from its repertoire. This allows the organism to evade the immune response in an infected host. ${ }^{34}$

Proteins attached through GPI are less tightly bound than their transmembrane counterparts, which allows a degree of transfer from one species (or cell) to another, as has been described in the parasitic infection caused by Schistosoma mansoni. In this case, the parasite seems to acquire host CD55, which in turn helps it to avoid complement mediated immune attack. $^{35}$

In addition to allowing "loss or gain" of proteins, the biochemical membrane associations and mobility are different for GPI anchors and transmembrane domains. It is possible that the anchor's characteristics and localisation are integral to the normal function of the associated protein.

GPI linked proteins are not randomly distributed over the cell membrane. In polar cells they are frequently located at the apical pole. In all cells, they associate with each other in regions of the membrane that are rich in glycolipids (sphingolipids and cholesterol), in so called glycolipid rafts. The importance of these structures remains unclear.

\section{The GPI abnormality in PNH}

Affected cells in PNH synthesise little or no GPI anchor. This results from a failure in the first step in the synthetic process-the addition of GlcNAc to PI. This has been demonstrated using different techniques by several workers. Biochemical studies using labelled precursors show an almost complete lack of intermediates containing mannose or glucosamine, indicating that the block in the pathway is at this first stage. ${ }^{36}$ Murine cell lines incapable of synthesising GPI structures have been studied. In these experiments it could be shown that lines in which the defect occurred at different points in the pathway complemented one another (restored the synthesis when fused together). Three lines, classes A, C, and H, were individually unable to add GlcNAc to PI but when fused together they complemented one another. ${ }^{37}{ }^{38}$ This implied that there were at least three gene products controlling this step. When PNH cells from patients are fused with these lines, they always complement cells of classes $\mathrm{C}$ and $\mathrm{H}$ but never those of class A. Thus, it became clear that the defect in PNH was always the same as that found in class A cells and led to a failure in the first step in GPI synthesis. ${ }^{39}$ This led to the subsequent discovery and expression cloning of the gene involved, which was termed PIG-A (phosphatidylinositol glycan complementation class 
A) ${ }^{16}$ It appears that the product of PIG-A, along with at least three other gene products (PIG-C, PIG-H, and hGPl), form the enzyme complex responsible for the transfer of GlcNAc to PI (R Watanabe et al. In: Proceedings of the International Symposium on Glycosyltransferases and cellular communication, 1997, Osaka, Japan, abstract 6).

\section{GPI linked proteins in PNH}

If no GPI molecule is produced then the unlinked proteins are degraded in the ER and are absent from the cell surface. ${ }^{40}$ Some can still be expressed in an alternative transmembrane bound form (for example, FCXRIII/CD16 or LFA-3/CD58), but whether they retain the same function is not clear. ${ }^{42} \mathrm{~A}$ further complicating factor in the analysis of surface phenotype in PNH is that some patients can synthesise small quantities of GPI anchor and there appears to be competition between proteins for this residue, leading to partial expression of certain molecules and complete absence of others. This is best observed in red blood cells that are divided into three types on this basis by flow cytometry. ${ }^{43}$ Type I are normal in their surface expression, type II show reduced but detectable amounts of GPI linked proteins, and type III are completely deficient. Patients with florid haemolysis usually have a large proportion of type III cells, whereas those with nonhaemolytic PNH in association with overt aplasia may have either type II cells or small type III clones. ${ }^{24}$ Type II cells probably arise in patients with PIG-A mutations that allow a small amount of residual protein to be produced-for example, some missense point mutations. ${ }^{44}$

A wide range of proteins use the GPI linkage mechanism for cell surface attachment. There is no obvious similarity between them, belonging as they do to different functional groups. They include complement defence proteins, enzymes, blood group antigens, adhesion molecules, cell receptors, and others of unknown function..$^{27}{ }^{4}$ If the proteins are normally expressed on haemopoietic cell lineages then they are absent in the cells of the PNH clone. Table 1 illustrates the diversity of proteins that have been described, although it is by no means exhaustive.

\section{"The high degree of interspecies conservation of the glycosyl phosphatidylinositol structure and its wide distribution argues for an important biological role for this mechanism of protein attachment"}

There is clearly a link between the clinical features of PNH and certain specific proteins lost through GPI synthetic failure. Understanding this would require a detailed understanding of the pathogenesis of the disease, which is at present incomplete. It would also require a full knowledge of the function of the proteins that are absent, which is also beyond us at present. Despite these problems, there are some associations that are quite well characterised and serve to whet our appetite. Most prominent among these is the intravascular haemolysis from which PNH derived its name. This is caused by a lack of one or more complement defence proteins from the red blood cell surface, allowing inappropriate and unopposed activation of complement. The candidate molecules include CD59 and CD55. Evidence from clinical studies, antibody blocking experiments, and gene transfer protocols favours CD59 as the most important molecule in this process, but a contribution from others cannot be ruled out. ${ }^{12} 1346$ The thrombotic tendency in PNH is less well understood but may also result from CD59 deficiency. ${ }^{47}$ In this scenario, complement activation on platelet surfaces leads to increased exovesiculation, which exposes phospholipid as a site for thrombin generation. The biological consequences of the loss of the myriad of other GPI linked proteins from cells is not clear. In many instances, because of an element of redundancy in most biological pathways, there may be no sequelae, and in others
Table 1 The range of glycosyl phosphatidylinositol (GPI) linked proteins

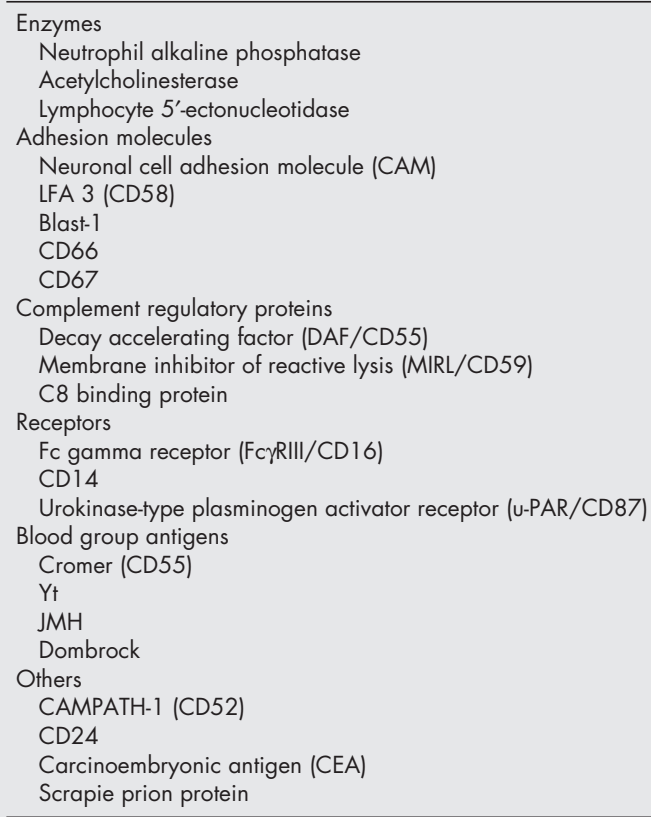

A partial list of proteins that are linked to the cell membrane by a GPI anchor and are therefore missing in paroxysmal nocturnal anchor and are therefore
haemoglobinuria cells.

the abnormalities may be subtle. The cause of the most intriguing feature of $\mathrm{PNH}$ clones-their relative growth advantage in a damaged bone marrow-remains obscure. It is possible that altered surface protein expression affects cellular responses or localisation within the microenvironment and the consequent alteration in the biology of the PNH cells allows them to evade the ongoing marrow insult and prosper in comparison with their normal counterparts. Our group has reported an example of abnormal localisation of haemopoietic stem cells in PNH. Most precursors in the peripheral blood of patients with PNH had the normal (non-PNH) phenotype, despite most bone marrow based progenitors being "PNH" in these individuals. We went on to show that treatment of these patients with granulocyte colony stimulating factor released largely PNH stem cells into the blood-altering the steady state. $^{48}$ Elucidation of the specific (presumably GPI linked) mechanisms by which this and other cellular interactions occur is the Holy Grail of PNH research. The answers may also have much to tell us about haemopoietic stem cell biology, the pathogenesis of bone marrow failure states, and the pathophysiology of autoimmunity.

\section{The PIG-A gene}

In 1993, Miyata et al described the expression cloning of the PIG-A gene by the correction of a GPI deficient murine cell line, which had a similar GPI biosynthetic defect to that observed in PNH. ${ }^{16}$ The PIG-A gene is somatically mutated in all cases of $\mathrm{PNH}$, presumably because it is the only gene of the GPI biosynthetic pathway that is found on the X chromosome at Xp22.1. ${ }^{17}{ }^{49}$ This means that a single mutation of the gene on the active $X$ chromosome of a haemopoietic stem cell in women or the only $X$ chromosome in men, will result in the PNH phenotype. The PIG-A gene consists of six exons spanning $17 \mathrm{~kb}$ of genomic DNA. It has an open reading frame of $1452 \mathrm{bp}$ encoding a protein of 484 amino acids. ${ }^{179}$ There is a short $5^{\prime}$ non-coding region with the initiation of transcription in exon 2 and a relatively large $3^{\prime}$ non-coding region. The 
A

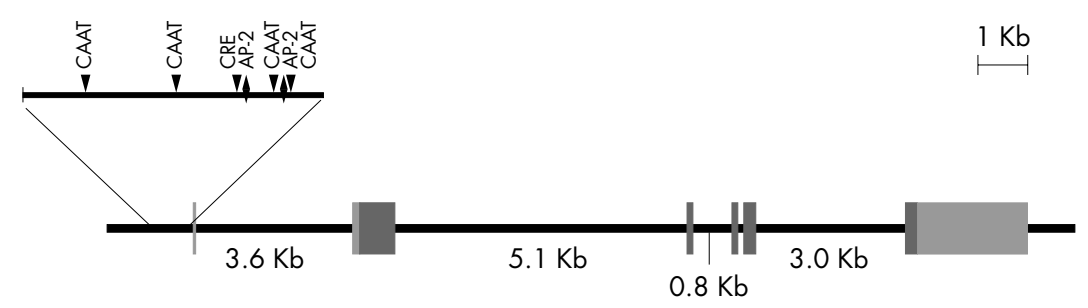

B

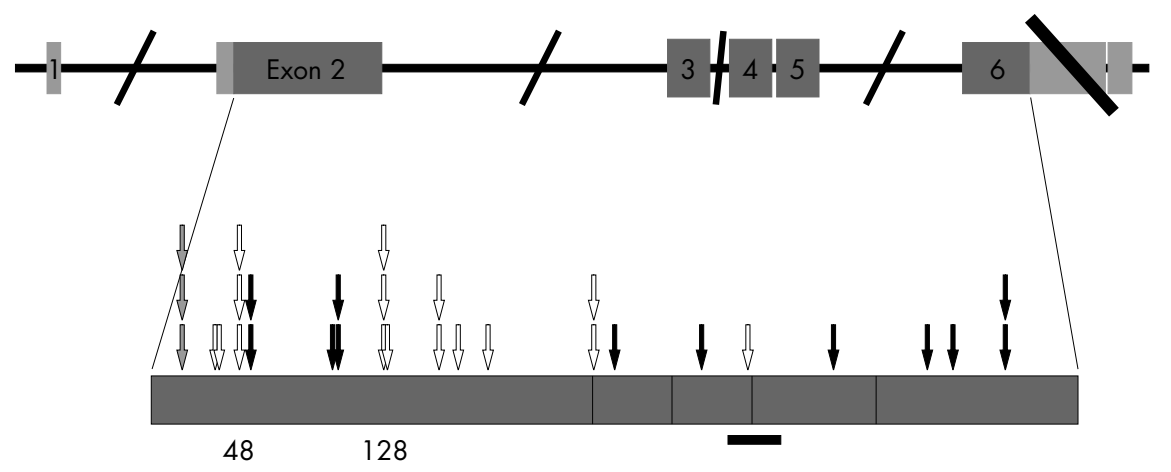

Figure 3 The PIG-A gene. (A) The genomic structure of the PIG-A locus. The promoter sequences of the PIG-A gene are depicted in greater detail and consist of four CAAT boxes, two AP-2 sequences, and a CRE (CAMP response element) sequence. These features are consistent with the ubiquitous expression of PIG-A. (B) The coding region of PIG-A. The reported point mutations are depicted by the arrows: the open arrows indicate missense mutation, the solid arrows are nonsense mutations, and the hatched arrows are at the site of a polymorphism that does not affect the code and has been reported in normal individuals. Codons 48 and 128 are affected by several different point mutations, indicating that these are potentially crucial areas of the PIG-A protein. The solid bar demonstrates the region of homology between PIG-A and several other glycosyltransferases, suggesting that it may be the binding site for $\mathrm{N}$-acetylglucosamine. One point mutation has been reported in this domain which resulted in a relatively neutral amino acid substitution (asparagine to aspartic acid) and a partial deficiency of glycosyl phosphatidylinositol linked antigens in this patient.

PIG-A promoter sequences are characteristic of a housekeeping gene, which presumably reflects the widespread expression of GPI linked proteins in all cell types.

\section{PIG-A mutations in PNH}

Because the mutations are somatic in $\mathrm{PNH}$, they are extremely varied, with very few reported more than once. $.^{39} 40-63$ Approximately two thirds are small insertions or deletions resulting in a frameshift and early termination of transcription. In this circumstance, no active PIG-A product is produced and the PNH cells are completely deficient in all GPI linked proteins. The remainder are point mutations and these may result in a complete or partial deficiency of GPI linked proteins. More than 100 PIG-A mutations have now been described and very few are repeated (fig 3).

In over half of affected patients, flow cytometric analysis of the red blood cells identifies two discrete populations of PNH cells (type III, with complete deficiency; and type II, with partial deficiency of GPI linked antigens). This indicates that there are at least two unrelated PNH clones in these patients. Several groups have now described patients with more than one PNH clone at a molecular level; in fact, as many as four separate GPI deficient clones with different PIG-A mutations have been identified in a single patient. ${ }^{64}$ In most cases, the individual clones occur at the same time, but one patient was studied before and many years after a bone marrow transplant, at the time of relapse, and the PIG-A mutations at relapse were different to those of the original disease.$^{65}$ In many of the cases with more than one mutated clone, red blood cell flow cytometry only identifies a single PNH population. Thus, it appears that most patients have multiple PNH clones. This indicates that patients are permissive for the development and/or expansion of PNH clones and therefore suggests a factor extrinsic to the PNH clone(s) that favours their development.

\section{Is a PIG-A deficient clone sufficient to result in PNH?}

The PIG-A gene is essential for embryogenesis and therefore mice that have "knocked out" PIG-A genes are not viable. When PIG-A deficient embryonic stem cells are microinjected into murine blastocysts, chimaeric mice are occasionally produced but only have a small number of cells derived from the PIG-A negative embryonic stem cells. ${ }^{66}{ }^{67}$ The deficient stem cells contribute to the haemopoietic compartment of the resulting chimaeric mice but their proportion in any individual mouse remains constant with time. In addition, when mice are produced with higher proportions of GPI deficient haemopoietic cells, by using the Cre-Lox P system and/or by transplantation experiments, the proportion of GPI deficient haemopoietic cells remains constant over time. ${ }^{68}$ These findings show that PNH cells do not have a growth advantage over their normal counterparts in mice without bone marrow failure.

"The cause of the most intriguing feature of paroxysmal nocturnal haemoglobinuria clones-their relative growth advantage in a damaged bone marrowremains obscure"

Araten and his colleagues recently reported the presence of rare GPI deficient neutrophils in normal individuals. ${ }^{69}$ These cells have a frequency of 10-51/million cells and when collected by flow sorting were shown to contain mutations of the PIG-A gene. These findings show that such mutations exist frequently among normal individuals, but this alone is not sufficient for the development of PNH.

\section{SUMMARY: THE DEVELOPMENT OF PNH}

We may now put forward a general outline of the factors leading to PNH and of its interplay with aplasia. The dual pathogenesis model appears to withstand the rigours of both time 
Take home messages

- It appears that the development of paroxysmal nocturnal haemoglobinuria $(\mathrm{PNH})$ requires two coincident factors: somatic mutation of the PIG-A gene and a hypoplastic bone marrow environment

- The gene mutation results in failure of synthesis of the glycosyl phosphatidylinositol (GPI) anchor, without which many proteins are unable to attach to cell surfaces

- It is thought that these alterations in surface antigen composition give the PNH cells a relative growth advantage in a hypoplastic marrow, although the precise pathophysiological mechanisms are unclear

- The failure of GPI production results in the loss of complement defence proteins from red blood cells, which explains the classic feature of intravascular complement mediated haemolysis

- There is indirect evidence that platelet activation with consequent thrombosis is caused by a similar mechanism

and experimental research. In this hypothesis, somatic mutations in PIG-A lead to PNH only if the affected cells are in a bone marrow under hypoplastic stress. The mutation and the abnormal bone marrow environment are both required. PNH cells possess only a relative growth advantage and will not prosper in a normal bone marrow.

If this is correct, then certain observations would be expected. Hypoplasia should be found invariably. This clinical association has of course been long recognised. Some degree of single or multiple cytopenia can be found in up to $80 \%$ of cases and in others there is laboratory evidence of diminished progenitor growth potential. ${ }^{20}{ }^{70}$ It appears then, that hypoplasia and PNH do indeed go hand in hand. For dual pathogenesis, one would require PIG-A mutations to be frequent in normal individuals; otherwise the coincidence of such an occurrence in the rare disease of aplasia would be extraordinary. This was in fact suspected from the presence of multiple, separate mutations in certain patients with PNH and has now been confirmed by observations from several authors. $^{70}{ }^{71}$ So it appears that the concept of dual pathogenesis accounts for the observed facts.

The mechanism by which aplasia imparts a relative growth advantage to PNH cells is more speculative. Although few doubt the immune component in aplasia, it is unclear whether this is a primary alteration in the stem cell pool against which an immune response develops or an autoreactive state, where otherwise normal stem cells are targeted. In either scenario, the PNH cells may prosper by evading the immune destruction. This could be mediated directly by loss of a GPI linked "recognition molecule" or occur through altered biology or localisation of the cells through GPI linked mechanisms. The answers to these questions will not only enlighten PNH research but may greatly enhance our understanding of aplasia and stem cell behaviour.

\section{REFERENCES}

1 Strübing P. Paroxysmale haemoglobinurie. Dtsch Med Wochensch 1882;8:1-17.

2 Marchiafava E, Nazari A. Nuovo contributo allo studio degli itteri cronici emolitici. Policlinico (Sezmed) 1911;18:241-4.

3 Michelli F. Anaemia (splenomegalia) emolitica con emoglobinuria-emosiderinuria tipo Marchiafava. Haematologica $1931 ; 12: 101$.

4 Enneking J. Eine neue form intermittierender haemoglobinurie Haemoglobinuria paroxysmalis nocturia). Klinische Wochenschrift 1928;7:2045.

5 Hymans van den Bergh AA. Ictere haemolytique avec crises haemoglobinuriques. Revue de Medecine Intern 1911;31:63

6 Dacie JV, Israels MCG, Wilkinson JF. Paroxysmal nocturnal haemoglobinuria of the Marchiafava type. Lancet 1938;1:479-81.

7 Ham TH, Dingle JH. Studies on the destruction of red blood cells II. Chronic haemolytic anaemia with paroxysmal nocturnal haemoglobinuria. Certain immunological aspects of the haemolytic mechanism with special reference to serum complement. J Clin Invest 1939; 18:657-72.

8 Dacie JV, Gilpin A. Refractory anaemia (Fanconi type). Arch Dis Child 1944:19:155-62.

9 Beck WS, Valentine WN. Biochemical studies on leucocytes II. Phosphatase activity in chronic lymphatic leukaemia, acute leukaemia and miscellaneous haematological conditions. J Lab Clin Med 1951;38:245-53.

10 Dacie JV. Paroxysmal nocturnal haemoglobinuria. Proc $R$ Soc Med 1963:56:587-96.

11 Oni SB, Osunkoya BO, Luzzatto L. Paroxysmal nocturnal haemoglobinuria: evidence for monoclonal origin of abnormal red cells. Blood 1970;36: 145-52

12 Telen MJ, Green AM. The Inab phenotype: characterisation of the membrane protein and complement regulatory defect. Blood 1989:74:437-45

13 Yamashina $M$, Ueda E, Kinoshita T, et al. Inherited complete deficiency of $20 \mathrm{kD}$ homologous restriction factor (CD59) as a cause of PNH. N Engl J Med 1990;323: 1 184-91.

14 Low MG, Zilversmit DB. Role of phosphatidylinositol in attachment of alkaline phosphatase to membranes. Biochemistry 1980;19:3913-18.

5 Hillmen P, Bessler M, Mason P, et al. Specific defect in n-acetylglucosamine incorporation in the biosynthesis of the GPI anchor in cloned cells from patients with PNH. Proc Natl Acad Sci U S A 1993:90:5272-6.

16 Miyata T, Takeda J, Lida Y, et al. The cloning of PIG-A, a component in the early step of GPI anchor biosynthesis. Science 1993;259:1318-26.

17 Bessler M, Hillmen P, Longo L, et al. Genomic organisation of the X-linked gene (PIG-A) that is mutated in PNH and of a related autosomal pseudogene mapped to 12q21. Hum Mol Genet 1994;3:751-62.

18 Rosse WF, Ware RE. The molecular basis of paroxysmal nocturnal hemoglobinuria [review]. Blood 1995;86:3277-86.

19 Socie G, Mary JY, De GA, et al. Paroxysmal nocturnal haemoglobinuria: long-term follow-up and prognostic factors. French Society of Haematology. Lancet 1996;348:573-7.

20 Hillmen $\mathbf{P}$, Lewis $S M$, Bessler $M$, et al. Natural history of paroxysmal nocturnal hemoglobinuria. N Engl J Med 1995;333:1253-8.

21 Young NS. The problem of clonality in aplastic anaemia: Dr Dameshek's riddle, restated. Blood 1992;79:1385-92.

22 Marsh JC, Geary CG. Is aplastic anaemia a pre-leukaemic disorder? $\mathrm{Br}$ J Haematol 1991;77:447-52.

23 Hall SE, Rosse WF. The use of monoclonal antibodies and flow cytometry in the diagnosis of paroxysmal nocturnal haemoglobinuria. Blood 1996:87:5332-40.

24 Hillmen P, Richards SJ. Implications of recent insights into the pathophysiology of paroxysmal nocturnal haemoglobinuria. $\mathrm{Br} J$ Haematol 2000; 108:470-9

25 Richards SJ, Norfolk DR, Swirsky DM, et al. Lymphocyte subset analysis and glycosylphosphatidylinositol phenotype in patients with paroxysmal nocturnal haemoglobinuria. Blood 1998:92:1799-806.

26 Endo M, Beatty PG, Vreeke TM, et al. Syngeneic bone marrow transplantation without conditioning in a patient with paroxysmal nocturnal hemoglobinuria: in vivo evidence that the mutant stem cells have a survival advantage. Blood 1996;88:742-50.

27 Bessler M, Hillmen P. Somatic mutation and clonal selection in the pathogenesis and in the control of paroxysmal nocturnal haemoglobinuria. Semin Hematol 1998;35: 149-67.

28 Low MG. Glycosyl-phosphatidylinositol: a versatile anchor for cell surface proteins. FASEB J 1989;3:1600-6.

29 Ferguson MAH Low MG Cross GAM. Glycosyl-sn-1,2-dimyristylphosphatidylinositol is covalently linked to Trypanosoma brucei variant surface glycoprotein. J Biol Chem 1985;260: 14547-53

30 Englund PT. The structure and biosynthesis of glycosyl-phosphatidylinositol protein anchors. Annu Rev Biochem 1993;62:121-31.

31 Low MG, Saltiel AR. Structural and functional roles of glycosyl-phosphatidylinositol in membranes. Science 1988;239:268-77.

32 Vidugiriene J, Menon AK. The GPI anchor of cell surface proteins is synthesised on the cytoplasmatic face of the endoplasmatic reticulum. $J$ Cell Biol 1994; 127:333-41.

33 Davitz MA, Hereld D, Shak S, et al. A glycanphosphatidylinositol-specific phospholipase D in human serum. Science 1987:238:81-4.

34 Cross AGM. Cellular and genetic aspects of antigenic variation in trypanosomes. Annu Rev Immunol 1990;8:83-110.

35 Pearce EJ, Hall BF, Sher A, et al. Host-specific evasion of the alternative complement pathway by schistosomes correlates with the presence of a phospholipase $\mathrm{C}$-sensitive surface molecule resembling human decay accelerating factor. Immunology 1990;144:2751-6.

36 Hillmen P, Bessler M, Mason P, et al. Specific defect in n-acetylglucosamine incorporation in the biosynthesis of the GPI anchor in cloned cells from patients with PNH. Proc Natl Acad Sci U S A 1993;90:5272-6.

37 Stevens VL, Raetz CRH. Defective glycosylphosphatidylinositol biosynthesis in extracts of three Thy-1 negative lymphoma cell mutants. J Biol Chem 1991;266:10039-45.

38 Armstrong C, Schubert J, Ueda E, et al. Affected PNH T lymphocytes harbour a common defect in assembly of $\mathrm{N}$-acetyl-D-glucosamine inositol phospholipid corresponding to that in class A Thy-1 murine lymphoma mutants. J Biol Chem 1992;267:25347-51. 
39 Bessler $M$, Mason PJ, Hillmen $\mathrm{P}$, et al. Paroxysmal nocturnal haemoglobinuria is caused by somatic mutations in the PIG-A gene. EMBO J 1994;13:110-17.

40 Kodukula K, Amthaver R, Cines D, et al. Biosynthesis of GPI-anchored membrane proteins in cell free systems: GPI is an obligatory co-substrate for $\mathrm{COOH}$-terminal processing of nascent proteins. Proc Natl Acad Sci U S A 1992;89:4982-7.

41 Kurosaki T, Ravetch JV. A single amino acid in the GPI attachment domain determines the membrane topology of Fc gamma III. Nature 1989:342:805-10.

42 Dustin ML, Selvaraj P, Mattaliano RJ, et al. Anchoring mechanisms for LFA-3 cell adhesion glycoprotein at membrane surface. Nature 1988;329:846-52

43 Rosse WF. Variations in the red cells in paroxysmal nocturnal haemoglobinuria. Br J Haematol 1973;24:327-42.

44 Bessler M, Mason PJ, Hillmen P, et al. Mutations in the PIG-A gene causing partial deficiency of GPI-linked surface proteins (PNH II) in patients with PNH. Br J Haematol 1994;87:863-6.

45 Rosse WF. Phosphatidylinositol-linked proteins and paroxysmal nocturnal haemoglobinuria. Blood 1990;75:1595-601.

46 Rother RP, Rollins SA, Mennone J, et al. Expression of recombinant transmembrane CD59 in paroxysmal nocturnal hemoglobinuria B cells confers resistance to human complement. Blood 1994;84:2604-11.

47 Wiedmer T, Hall SE, Ortel TL, et al. Complement induced vesiculation and exposure of membrane prothrombinase sites in platelets of $\mathrm{PNH}$. Blood 1993:82:1192-9.

48 Johnson RJ, Rawstron A, Richards S, et al. Circulating primitive stem cells in PNH are predominantly normal in phenotype but G-CSF treatment mobilises mainly PNH stem cells. Blood 1998:91:4504-8.

49 lida Y, Takeda J, Miyata T, et al. Characterization of genomic PIG-A gene: a gene for glycosylphosphatidylinositol-anchor biosynthesis and paroxysmal nocturnal hemoglobinuria. Blood 1994;83:3126-31.

50 Takeda J, Miyata T, Kawagoe K, et al. Deficiency of the GPI anchor caused by a somatic mutation of the PIG-A gene in paroxysmal nocturnal hemoglobinuria. Cell 1993:73:703-11.

51 Bessler M, Mason PJ, Hillmen P, et al. Somatic mutations and cellular selection in paroxysmal nocturnal haemoglobinuria. Lancet 1994;343:951-3.

52 Ware RE, Rosse WF, Howard TA. Mutations within the Pig-a gene in patients with paroxysmal nocturnal hemoglobinuria. Blood 1994:83:2418-22

53 Yamada N, Miyata T, Maeda K, et al. Somatic mutations of the PIG-A gene found in Japanese patients with paroxysmal nocturnal hemoglobinuria. Blood 1995:85:885-92.

54 Ostendorf T, Nischan C, Schubert J, et al. Heterogeneous PIG-A mutations in different cell lineages in paroxysmal nocturnal hemoglobinuria. Blood 1995;85:1640-6.

55 Pramoonjago P, Wanachiwanawin W, Chinprasertsak S, et al. Somatic mutations of PIG-A in Thai patients with paroxysmal nocturnal hemoglobinuria. Blood 1995;86:1736-9
56 Nafa K, Mason PJ, Hillmen P, et al. Mutations in the PIG-A gene causing paroxysmal nocturnal hemoglobinuria are mainly of the frameshift type. Blood 1995;86:4650-5.

57 Nagarajan S, Brodsky RA, Young NS, et al. Genetic defects underlying paroxysmal nocturnal hemoglobinuria that arises out of aplastic anemia. Blood 1995:86:4656-61.

58 Savoia A lanzano L, Lunardi $C$, et al. Identification of three novel mutations in the PIG-A gene in paroxysmal nocturnal haemoglobinuria (PNH) patients. Hum Genet 1996;97:45-8.

59 Nafa K, Bessler M, Castro-Malaspina H, et al. The spectrum of somatic mutations in the PIG-A gene in paroxysmal nocturnal hemoglobinuria includes large deletions and small duplications. Blood Cells Mol Dis 1998:24:370-84

60 Azenishi Y, Ueda E, Machii T, et al. CD59-deficient blood cells and PIG-A gene abnormalities in Japanese patients with aplastic anaemia. $B$ J Haematol 1999; 104:523-9

61 Nishimura J, Murakamia Y, Kinoshita T. Paroxysmal nocturnal hemoglobinuria: an acquired genetic disease. Am J Hematol 1999;62:175-82.

62 Purow DB, Howard TA, Marcus SJ, et al. Genetic instability and the etiology of somatic PIG-A mutations in paroxysmal nocturnal hemoglobinuria. Blood Cells Mol Dis 1999;25:81-91.

63 Mortazavi Y, Tooze JA, Gordon-Smith EC, et al. N-RAS gene mutation in patients with aplastic anemia and aplastic anemia/paroxysmal nocturnal hemoglobinuria during evolution to clonal disease. Blood 2000:95:646-50.

64 Nishimura J, Inove N, Wada H, et al. A patient with paroxysmal nocturnal hemoglobinuria bearing four independent PIG-A mutant clones. Blood 1997;89:3470-6.

65 Nafa K, Bessler M, Deeg HJ, et al. New somatic mutation in the PIG-A gene emerges at relapse of paroxysmal nocturnal hemoglobinuria. Blood 1998:92:3422-7

66 Rosti V, Tremml G, Soares V, et al. Murine embryonic stem cells without pig-a gene activity are competent for hematopoiesis with the $\mathrm{PNH}$ phenotype but not for clonal expansion. J Clin Invest 1997;100:102836.

67 Kawagoe K, Kitamura D, Okabe M, et al. Glycosylphosphatidylinositol-anchor-deficient mice: implications for clonal dominance of mutant cells in paroxysmal nocturnal hemoglobinuria. Blood 1996:87:3600-6.

68 Tremml G, Dominguez C, Rosti V, et al. Increased sensitivity to complement and a decreased red blood cell life span in mice mosaic for a nonfunctional PIG-A gene. Blood 1999;94:2945-54.

69 Araten DJ, Nafa K, Pakdeesuwan K, et al. Clonal populations of hematopoietic cells with paroxysmal nocturnal hemoglobinuria genotype and phenotype are present in normal individuals. Proc Natl Acad Sci U S A $1999 \cdot 96: 5209-14$.

70 Rotoli B, Luzzatto L. Decreased numbers of circulating BFU-Es in PNH. Blood 1989;60: 157-9.

71 Rawstron AC, Rollinson SJ, Richards S, et al. GPI deficient cells (PNH phenotype) are present in most normal individuals. Blood 1997;90(suppl 1):273a.

\section{Call for peer reviewers}

Clinical Evidence is a regularly updated evidence based journal available world wide both as a paper version and on the internet. Clinical Evidence urgently needs to recruit a number of new contributors. Contributors are health care professionals or epidemiologists with experience in evidence based medicine and the ability to write in a concise and structured way.

Clinical Evidence needs to recruit a number of new peer reviewers. Peer reviewers are health care professionals or epidemiologists with experience in evidence based medicine. As a peer reviewer you would be asked for your views on the clinical relevance, validity and accessibility of specific topics within the journal, and their usefulness to the intended audience (international generalists and health care professionals, possibly with limited statistical knowledge). Topics are usually 2000-3000 words in length and we would ask you to review between 2-5 topics per year. The peer review process takes place throughout the year, and our turnaround time for each review is ideally 10-14 days.

If you are interested in becoming a peer reviewer for Clinical Evidence, please complete the peer review questionnaire at www.clinicalevidence.com or contact Polly Brown (pbrown@bmigroup.com). 


\title{
ORIGINAL ARTICLE
}

\section{Alterations of the MDV oncogenic regions in an MDV transformed lymphoblastoid cell line}

\author{
E Le Rouzic, P Thoraval, M Afanassieff, Y Cherel, G Dambrine, B Perbal
}

J Clin Pathol: Mol Pathol 2002;55:262-272

See end of article for authors' affiliations

\section{Correspondence to:}

Professor B Perbal, UFR de Biochimie, Université Paris 7-D. Diderot, 2 Place Jussieu, 75005 Paris, France;

Bernard.Perbal@wanadoo.fr

Accepted for publication 8 May 2002

This manuscript is dedicated to the memory of Pierrick.

\begin{abstract}
Aims: Lymphoblastoid cell lines derived from Marek's disease virus (MDV) induced tumours have served as models of MDV latency and transformation. They are stable and can be cultured with no detectable MDV genomic alterations upon repeated passaging. An MDV transformed lymphoblastoid T cell line (T9 cell line) has been reported to contain a disrupted MDV BamHI-H fragment and a Rous associated virus insertional activation of the c-myb protooncogene. In an attempt to define the respective participation of $c-m y b$ and MDV in the transformed phenotype of T9 cells, an analysis of MDV oncogenic sequences (BamHI-H, BamHI-A, and EcoQ fragments) was performed in these cells.

Methods: Using two different passages of the T9 cell line (late and early passages), the organisation of the MDV oncogenic regions and their expression in these cells were analysed. In vivo assessment of the oncogenicity of the virus contained within these cells was assessed by injecting them into 1 day old chickens.

Results: In T9 cells maintained in culture for up to six months (late T9), the MDV ICP4 gene was disrupted, whereas the meq gene was actively transcribed. The alterations of the MDV genome in these cells correlated with the inability of the virus to induce the classic signs of Marek's disease in 1 day old chickens. However, early T9 cells submitted to a limited number of passages induced classic MDV pathogenicity, as efficiently as the MDV control cell line (T5), and did not show gross structural changes in the oncogenic MDV sequences.

Conclusions: Although the expression pattern of the MDV oncogenes in early T9 cells was identical to the one reported for other MDV transformed cells, longterm culture of an MDV transformed cell line containing a RAV insertional activation of the c-myb protooncogene led to the disruption of the MDV BamHI-H and BamHI-A oncogenic regions. In the late T9 cells MEQ was the only detected MDV oncoprotein. These results suggest that in the late T9 cells the truncated MYB protein compensates for the loss of MDV oncoproteins and reinforce the possibility that MEQ and MYB cooperate in the maintenance of the transformed state and the tumorigenic potential of these cells.
\end{abstract}

M arek's disease virus (MDV) is an avian herpesvirus that causes $\mathrm{T}$ cell lymphomas and mononuclear infiltration in peripheral nerves, leading to paralysis within four to six weeks in susceptible chickens. ${ }^{1}$ The MDV genome, co-linear with $\alpha$ herpesvirus genomes, is $180 \mathrm{~kb}$ long and consists of short and long unique regions ( $\mathrm{U}_{\mathrm{S}}$ and $\mathrm{U}_{\mathrm{L}}$, respectively), flanked by terminal repeats $\left(\mathrm{TR}_{\mathrm{L}}\right.$ and $\mathrm{TR}_{\mathrm{S}}$, respectively), and internal repeats $\left(\mathrm{IR}_{\mathrm{L}}\right.$ and $\mathrm{IR}_{\mathrm{S}}$, respectively). ${ }^{2-4}$

The rapid onset of tumours suggests the presence of MDV encoded oncogene(s). However, little is known about the molecular mechanisms of MDV induced oncogenesis. Several experimental approaches have been taken to identify viral genes that may be involved in the process of oncogenesis. These approaches include the analysis of: (1) the regions of the MDV genome that undergo alteration during attenuation of oncogenic strains (serotype 1); (2) the viral gene products expressed in MDV induced tumours and tumours derived from lymphoblastoid cell lines; and ( 3 ) the viral gene products of the serotype 1 strain, which are absent in the nononcogenic serotype $2 \mathrm{MDV}$ and serotype 3 herpesviruses of turkey strains. At least 15 open reading frames (ORFs) mapping mainly within four BamHI fragments (BamHI-H, BamHI- $\mathrm{I}_{2} / \mathrm{Q}_{2}$, and BamHI-A) spanning the $\mathrm{IR}_{\mathrm{L}}$ and the $\mathrm{IR}_{\mathrm{S}}$ are expressed in transformed lymphocytes.

"Much evidence has accumulated to suggest that MEQ might play a role in oncogenesis: it is consistently expressed in most MDV infected cells, in transformed cell lines, and in CD4+ T cells from lymphomas"
Initially, it was noted that serial in vitro passages of oncogenic MDV strains in primary chicken embryo fibroblasts (CEFs) led to a loss of tumorigenicity. ${ }^{6-8}$ This change was shown to be associated with the amplification (up to 100 copies) of a $132 \mathrm{bp}$ repeat within the BamHI-H and BamHI-D fragments. ${ }^{90}$ In lymphoblastoid cell lines carrying attenuated MDV strains, this amplification results in the expression of truncated RNA species from the $1.8 \mathrm{~kb}$ family. ${ }^{11}$ Kawamura et al have reported that oligonucleotides complementary to the predicted splice donor site in the $1.8 \mathrm{~kb}$ family inhibit proliferation of MDV cell lines. ${ }^{12}$ The transfection of CEFs with two cDNAs isolated from this family of transcripts resulted in reduced serum dependence and prolonged proliferation of these cells. ${ }^{13}$ Four alternatively spliced and unspliced RNAs spanning the $132 \mathrm{bp}$ repeat have been identified in CEFs infected with an oncogenic MDV strain, and at least two ORFs have been characterised, although their function remains unclear. $^{14}{ }^{15}$ Another protein, the phosphoprotein pp38, is expressed from this region. Its gene is transcribed in the opposite orientation and overlaps the $\mathrm{U}_{\mathrm{L}}$ and $\mathrm{IR}_{\mathrm{L}}$ junction. The

Abbreviations: CEF, chicken embryo fibroblast; GAPDH, glyceraldehyde-3-phosphate dehydrogenase; $I_{L^{\prime}}$ long internal repeat; $I_{S}$ short internal repeat; LATs, latency associated transcripts; MDV, Marek's disease virus; MHC, major histocompatibility complex; ORF, open reading frame; PBS, phosphate buffered saline; RAV-2, Rous associated virus 2; TAE, Tris acetate EDTA; $T_{L}$, long terminal repeat; $T_{S}$, short terminal repeat; $U_{S}$, short unique region; $U_{L}$, long unique region 


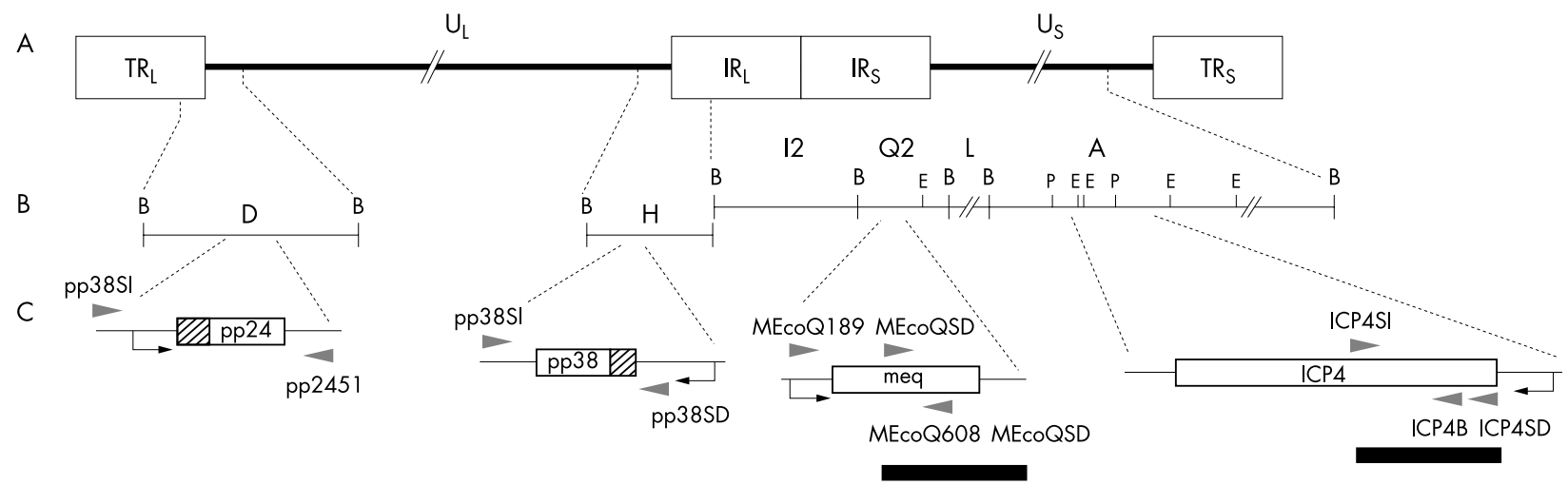

Figure 1 (A) Genomic structure of Marek's disease virus (MDV). MDV consists of long and short unique sequences $\left(U_{L}\right.$ and $U_{S}$, respectively), flanked by long and short internal repeats $\left(\mathbb{R}_{L}\right.$ and $I R_{S}$, respectively), and long and short inverted terminal repeats $\left(T_{L}\right.$ and $T_{S}$, respectively). (B) Locations of the BamHI-D, BamHI-H, BamHI-I2, BamHI-Q2, BamHI-L, and BamHI-A regions. A detailed restriction map is indicated (E, EcoRI; B, BamHI; P, Pvull). (C) Locations of the pp24, pp38, meq, and ICP4 homologue genes. Corresponding gene regions are enlarged to show the open reading frame and the transcription sense (arrow); the localisations of the oligonucleotides (arrowhead) used for PCR and Southern blotting are indicated. A solid bar represents the resulting amplified product used as a probe.

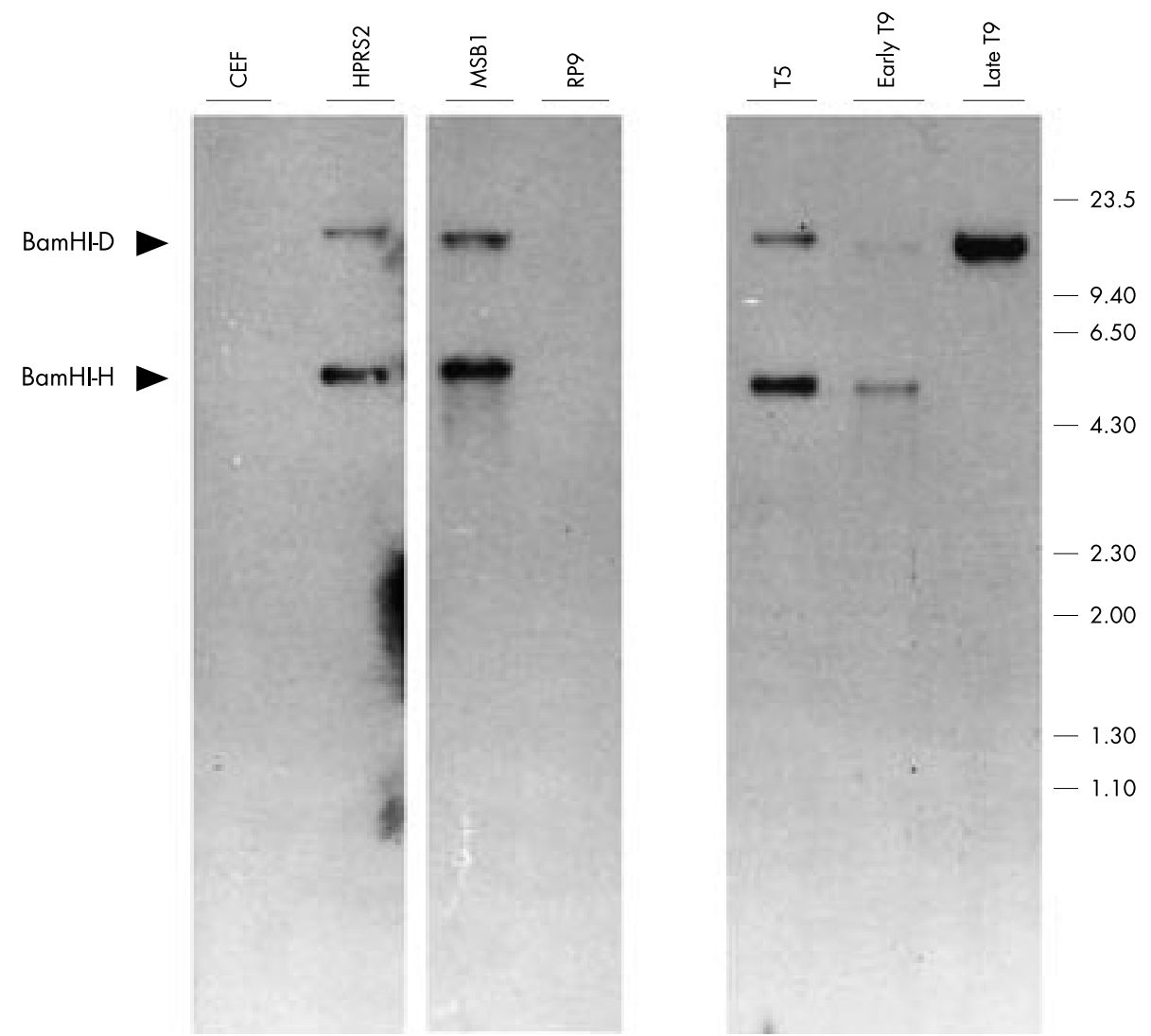

Figure 2 Disruption of Marek's disease virus (MDV) BamHI-H fragment in late T9 DNA. Southern blots of BamHI digested high molecular weight DNA $(15 \mu \mathrm{g})$ were hybridised with the $\left[{ }^{32} \mathrm{P}\right]$ labelled MDV specific $5.4 \mathrm{~kb}$ BamHI-H probe. ${ }^{10}$ DNA samples from chicken embryo fibroblasts (CEFs) were used as negative control. Molecular weight markers (in kilobases) are from Hindlll digested $\lambda$ DNA.

BamHI-D fragment encodes a phosphoprotein, pp24, the transcripts of which overlap $\mathrm{TR}_{\mathrm{L}}$ and $\mathrm{U}_{\mathrm{L}}{ }^{16}$ Both of these proteins are expressed in lytically infected cells and at a lower degree in lymphoblastoid cell lines. ${ }^{17}$ The use of antisense strategies suggested that pp38 might play a role in the proliferation of the MDV transformed cell line, MSB- $1 .{ }^{12} 18$

The MDV ICP4 gene maps to the BamHI-A fragment, within the $I_{S}$ flanking the $U_{L}$ region of the MDV. It encodes an immediate-early transactivator that plays a crucial role in the regulation of transcription during MDV replication. ${ }^{19}{ }^{20}$ Oligonucleotides complementary to the translation start region of ICP4 and the expression of antisense RNA inhibited the growth of MSBl cells, indicating that the ICP4 gene might be required for the maintenance of the transformed state. ${ }^{18}$ Latency associated transcripts (LATs) expressed in lymphoblastoid cell lines and lytically infected CEFs ${ }^{21-23}$ are complementary to ICP4. It has been suggested that the LATs could regulate the expression of ICP4 and thus contribute to transformation by preventing replication of the virus. ${ }^{20}$

The best characterised candidate MDV oncogene is the EcoRI-Q protein (MEQ), which is expressed from the adjacent BamHI-I2 and BamHI-Q2 fragments in the $\mathrm{IR}_{\mathrm{L}}$. Much evidence has accumulated to suggest that MEQ might play a role in oncogenesis: it is consistently expressed in most MDV infected 


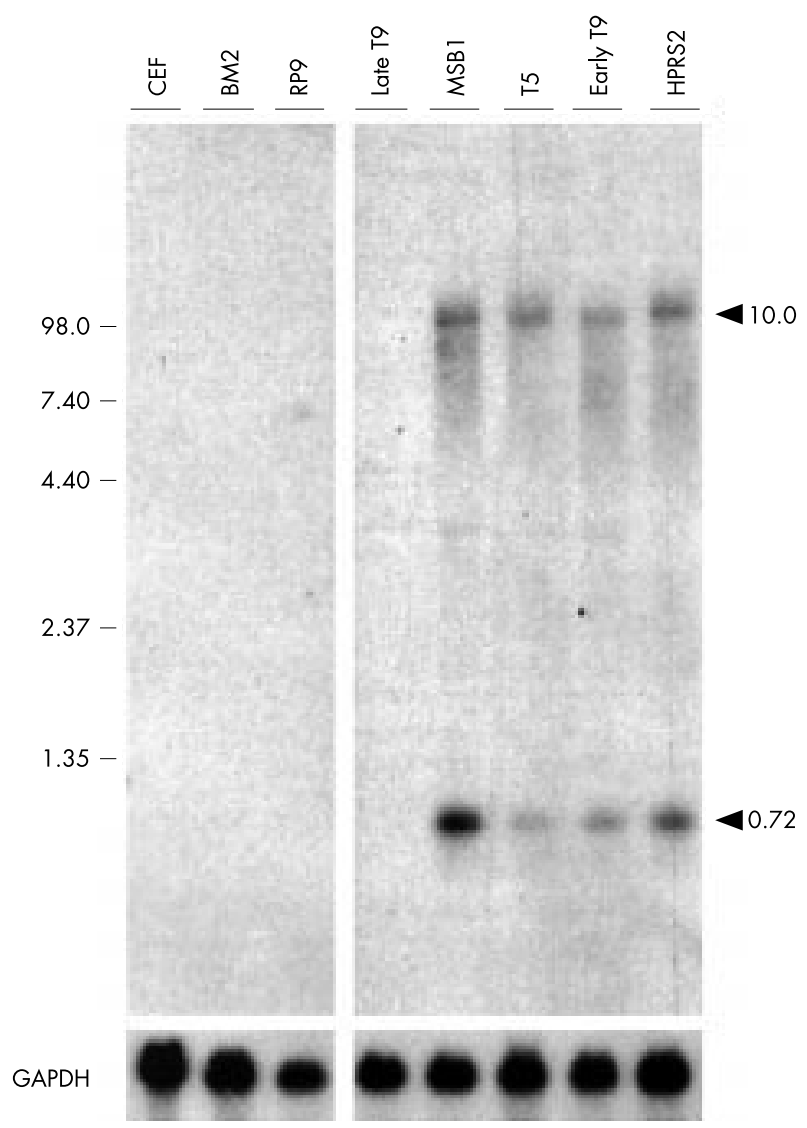

Figure 3 Analysis of the ICP4 gene region. Expression of RNA species in Marek's disease virus (MDV) transformed cell lines. Northern blots were performed with $20 \mu \mathrm{g}$ samples of total RNA, and were sequentially probed with [32P] labelled ICP4 and glyceraldehyde-3-phosphate dehydrogenase (GAPDH) double strand fragments. Chicken embryo fibroblasts (CEFs) and BM2 RNA samples were used as negative controls. Size markers in kilobases correspond to the BRL RNA ladder.

cells, in transformed cell lines, and in CD4+ T cells from lymphomas. ${ }^{24-26}$ The expression of RNA complementary to meq can prevent the growth of the MSBl cell line, ${ }^{18}$ and overexpression of meq in rat-2 fibroblasts by recombinant murine retrovirus led to cell transformation. ${ }^{27}$ The MEQ protein is a transactivating b-Zip protein that homodimerises or heterodimerises in vitro with c-Jun, c-Fos, and cAMP response element binding protein. ${ }^{24}{ }^{28-30}$ It has antiapoptotic activities, ${ }^{27}$ and was proposed to promote cell cycle progression. ${ }^{28}$ However, MEQ alone is not capable of transforming primary CEFs and the injection of chickens with replication defective virus carrying meq yielded a low incidence of sarcomas (5\%), which eventually metastasised into internal organs. ${ }^{27}$

Altogether, these observations indicated that none of the viral genes is sufficient on its own for the induction and/or the maintenance of transformation of lymphoid cells in Marek's disease. The close relation seen in the regulation of their expression suggested a synergistic action between these different viral genes. The pp38 promoter contains an ICP4 responsive element and transfection of MSB-1 cells by an ICP4 expression plasmid correlates with overexpression of the pp24 and pp38 phosphoproteins. ${ }^{31}$ The MEQ homodimer can bind to at least two distinct motifs (MERE I and II). A MERE II element is present in the putative MDV origin of replication, which overlaps the bidirectional promoter of the pp38 gene and the $1.8 \mathrm{~kb}$ family gene. ${ }^{30}$

We have previously reported that, in addition to an altered MDV BamHI-H fragment, the MDV transformed T9 cells also contained a c-myb insertional activation. These results sug- gested that the maintenance of the transformed state was dependent upon the presence of a truncated c-MYB protein. ${ }^{32}$ To test this hypothesis, we analysed the putative oncogenic regions from the MDV in the T9 cell lines. Here, we report that, except for the meq gene, MDV regions encoding putative oncogenes are altered in T9 cells, therefore raising the possibility that maintenance of transformation in this cell line might require cooperation between the meq and truncated myb oncogenes.

\section{MATERIALS AND METHODS \\ Cells}

The T9 and T5 T cell lymphoma cell lines were isolated from two testicular tumours obtained after the injection of MDV (HPRS16 strain) into 1 day old white leghorn chickens. The injection of T9 and T5 cells into chickens induced Marek's disease at the time the cell lines were established. T cell antigens have been characterised on the surface membrane of T9 cells $^{33}$ and the T9 cell line has been used in cytotoxicity assays. ${ }^{34}$ The two other Marek's disease cell lines were isolated in different laboratories: MDCCMSB1 was derived from a splenic lymphoma ${ }^{35}$ and HPRS2 was derived from an ovarian lymphoma. ${ }^{36}$ The RP9 cell line was established from a Rous associated virus 2 (RAV-2) induced B transplantable lymphoma. ${ }^{37}$ These cell lines were grown in RPMI 1640 medium supplemented with $10 \%$ fetal calf serum. The BM2 myeloblastic cell line was obtained from a chicken infected with avian myeloblastosis virus. ${ }^{38}$ BM2 cells were grown in DMEM medium supplemented with $10 \%$ fetal calf serum, $10 \%$ tryptose phosphate broth, and $2 \%$ heat inactivated chicken serum. CEFs were prepared from 13 day old C/E brown leghorn embryos (gs+, chf,$+ \mathrm{V}-$ ) of the Edinburgh strain, and cultured as described elsewhere. ${ }^{39}$ All cultures were performed at $37^{\circ} \mathrm{C}$ in a $5 \% \mathrm{CO}_{2}$ atmosphere.

\section{In vivo infectivity assays}

The GBl strain of inbred chickens bearing the major histocompatibility complex (MHC) haplotype B13 was used in these studies. ${ }^{40}$ These chickens were free from specific pathogens, lacked maternal antibodies directed against MDV, and were highly susceptible to Marek's disease. At hatching, three groups of chickens were injected intraperitoneally with $10^{7} \mathrm{~T} 5$ or T9 cells. In each group, eight to nine chicks were injected and six were used as internal controls to assess the horizontal transmission of MDV. Birds were euthanised and necropsied upon signs of morbidity. Organs with Marek's disease lesions were harvested, processed for histological examination, and frozen for subsequent DNA isolation. Histological examinations of the nerves were systematically performed.

\section{Southern blot analysis}

High molecular weight DNA was purified from primary cells, cell lines, and solid tumours as described previously. ${ }^{41}$ After restriction endonuclease (GIBCO-BRL, Cergy Pontoise, France) digestion and electrophoresis in horizontal 0.8\% TAE (Tris/acetate/EDTA electrophoresis buffer) agarose gels, DNA fragments were transferred on to Nytran membranes (Schleicher and Schuell, Dassel, Germany). Hybridisation to $\left[{ }^{32} \mathrm{P}\right]$ labelled probes was performed as described elsewhere. ${ }^{41}$ All probes were prepared from purified DNA inserts.

\section{RNA purification and analysis}

Total RNA was prepared from cultured cells, using the guanidinium isothiocyanate method and northern blotting analysis was performed under the conditions described previously. $^{41}$

\section{Polymerase chain reaction}

DNA from whole cellular lysates, prepared as described, ${ }^{42}$ and purified high molecular weight DNA were subjected to polymerase chain reaction (PCR) amplification using Taq DNA polymerase (Appligene, Paris, France) in a Perkin-Elmer Cetus 


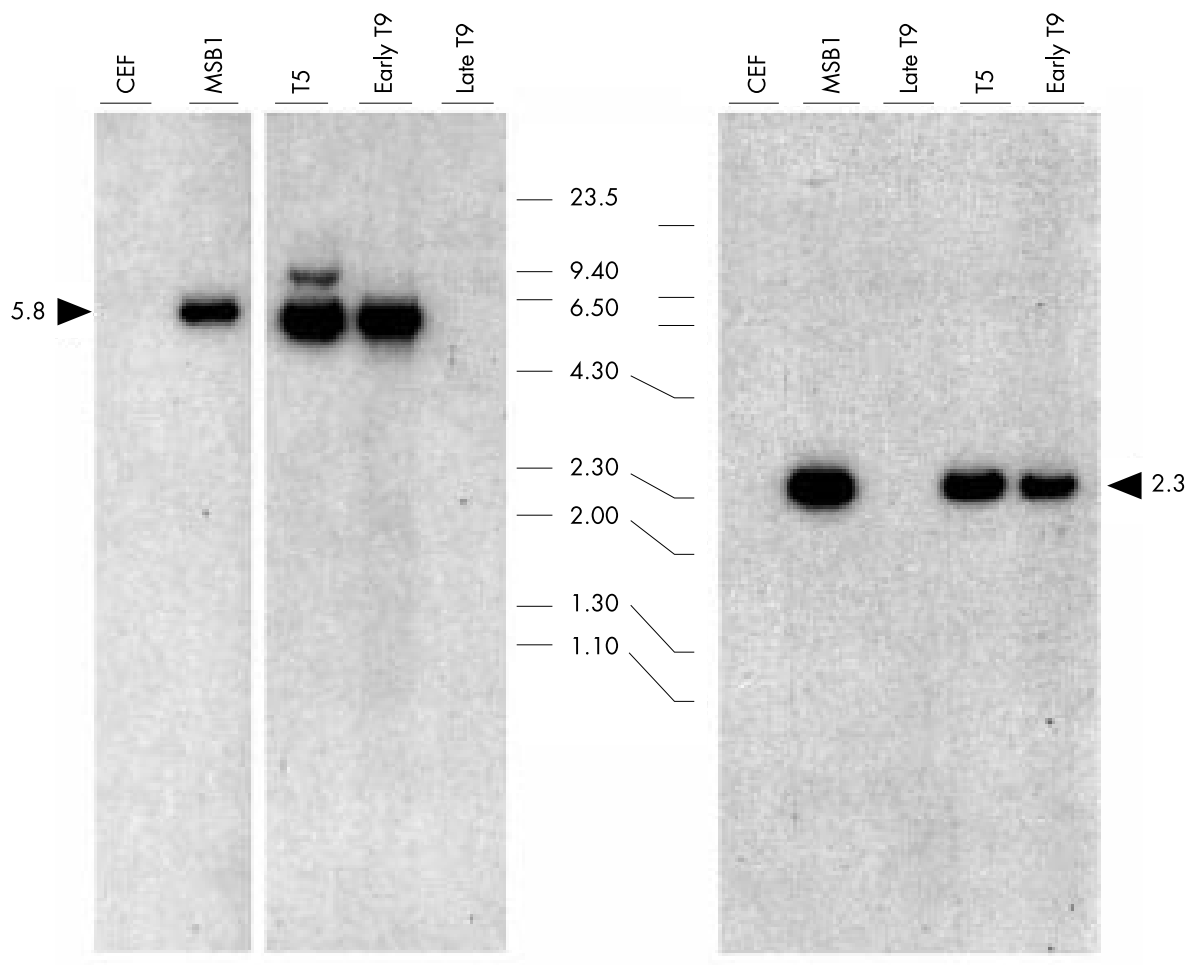

Figure 4 Analysis of the ICP4 homologue gene region. Southern blot analysis. DNA (15 $\mu$ g) digested with EcoRI (left hand panel) or Pvull (right hand panel) from the indicated cells was run on a $0.8 \%$ agarose gel and then blotted and hybridised with the ICP4 probe. Molecular weight markers (in kilobases) are from Hindlll digested $\lambda$ DNA. CEF, chicken embryo fibroblast.

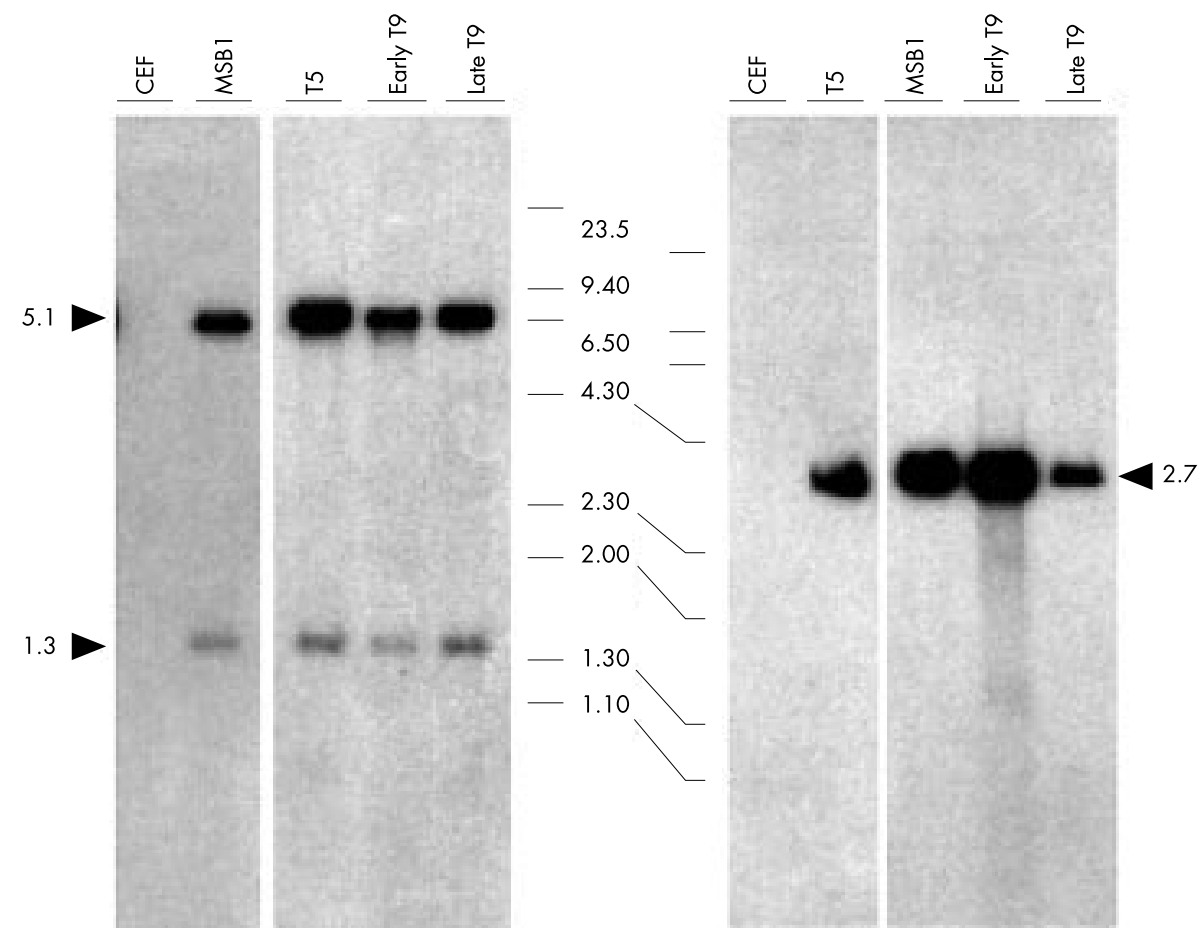

Figure 5 Analysis of the Eco-Q region encoding the meq gene. Southern blot analysis. DNA (15 $\mu$ g) digested with BamHI (left hand panel) or EcoRI (right hand panel) from the indicated cells was blotted and hybridised with the meq probes. Chicken embryo fibroblast (CEF) and RP9 digested DNA samples were used as negative controls. Molecular weight markers (in kilobases) are from Hindlll digested $\lambda$ DNA.

thermocycler. PCR conditions were as described previously. ${ }^{32}$ The primers for the pp38 gene used for amplification were as follows (5' to 3'): pp38SD, GCTGCAGCTGTCCATTTTCC; pp38SI, GCCATCCTTGTCTTTCTGCC; and pp38I, CTGCTTCGAATTCCATCACC (nt 1529 to 1549,2564 to 2584 , and 2500 to 2519 , $^{10}$ respectively). The primer for the pp24 gene was as follows: pp24SI, ACCCCGTAACCAGCATGATG (nt 1411 to $1431^{43}$ ). The primers for the ICP4 gene were as follows: ICP4SI, GCCATGGGATGTGTTGAATCT; ICP4SD, CAACGCCAATATGGACGATGA; and ICP4B, TGAGACTTCACCGTCAAATG (nt 1395 to 


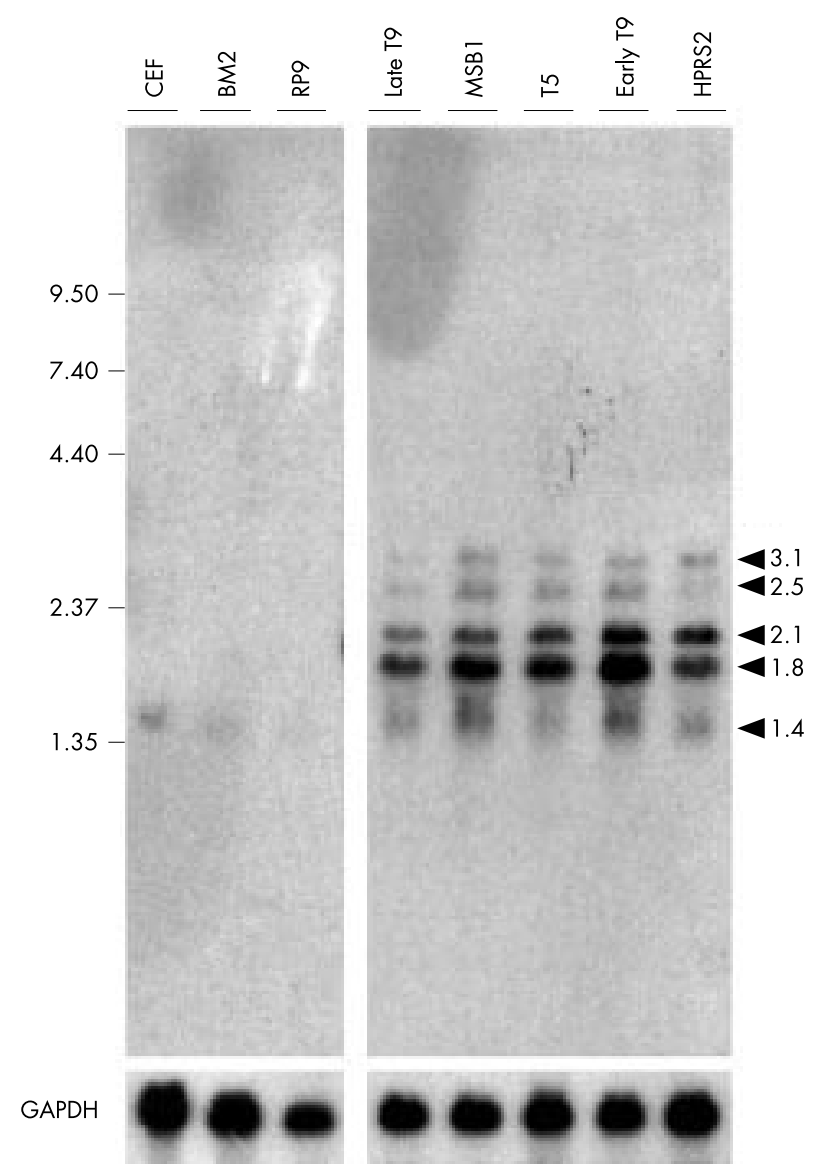

Figure 6 Analysis of the Eco-Q region encoding the meq gene. The expression of meq RNA species in Marek's disease virus transformed cell lines. Northern blots were performed with $20 \mu \mathrm{g}$ samples of total RNA from the indicated cells, and were sequentially hybridised with [2P] labelled probes meq and glyceraldehyde-3-phosphate dehydrogenase (GAPDH) double strand fragments. Chicken embryo fibroblast (CEF) and BM2 RNA samples were used as negative controls. The size markers (in kilobases) correspond to the BRL RNA ladder.

1415, 2224 to 2244 , and 1638 to $1657,{ }^{19}$ respectively). The primers for the meq gene were as follows: MEcoQSD, ACATTGCTCCGGTTCCCAAC; MECoQSI, ATAGACGATGTGCTGCTGAG; and MEcoQ, TATGGGGAGTAGAGATGGGA (nt 843 to 862,1392 to 1411 , and 933 to $952,{ }^{24}$ respectively). PCR products were separated on TAE agarose gels and analysed by Southern blot hybridisation with labelled internal oligonucleotide probes (pp38I, ICP4B, and MECoQ), as described previously. ${ }^{41}$

\section{Nucleic acid probes}

DNA fragments were Geneclean (Biol01) purified, and labelled with $\left[\alpha^{32} \mathrm{P}\right]$ dCTP (ICN, Orsay, France) by nick translation (Invitrogen, Cergy Pontoise, France). The MDV specific probe corresponded to the BamHI-H fragment localised at the junction between the $\mathrm{U}_{\mathrm{L}}$ and $\mathrm{IR}_{\mathrm{L}}{ }^{10}{ }^{10}$ The meq and ICP4 DNA probes were obtained from PCR amplified fragments using DNA isolated from the MSBl cell line and specific oligonucleotides (fig 1). The PCR products were sequenced and cloned in the pMOSBlue plasmid vector (Amersham, Orsay, France). Avian glyceraldehyde-3-phosphate dehydrogenase (GAPDH $)^{44}$ was used as an internal standard to assess the amount of RNA present in each sample.

\section{Immunoblot assays}

Cells were lysed in RIPA buffer $(50 \mathrm{mM}$ Tris/HCl, pH 8.0, $150 \mathrm{mM}$ sodium chloride, $0.1 \%$ sodium dodecyl sulfate, $0.5 \%$ sodium deoxycholate, $1.0 \%$ NP40, and $5 \mathrm{mM}$ EDTA); $5 \mu \mathrm{g} / \mathrm{ml}$ of leupeptin, antipain, chymostatin, pepstatin; 0.4 TIU of aprotinin/ml (trypsin inhibiting units); and $2 \mathrm{mM}$ of aminoethyl-benzenesulfonyl fluoride (Sigma, Saint Quentin Fallavier, France). Lysates were clarified by centrifugation at
$10000 \times g$ for 15 minutes at $4^{\circ} \mathrm{C}$ and supernatants were stored frozen at $-70^{\circ} \mathrm{C}$ until analysis. Samples of protein extracts solubilised in Laemmli buffer were separated by sodium dodecyl sulfate-polyacrylamide gel electrophoresis and electroblotted on to a PVDF membrane (Immobilon P; Millipore, Strasbourg, France). Filters were incubated overnight at $4^{\circ} \mathrm{C}$ in phosphate buffered saline (PBS) containing $4 \%$ non-fat dried milk and $0.05 \%$ Tween 20 , before probing with the appropriate antiserum for one hour at $37^{\circ} \mathrm{C}$. Filters were rinsed three times in PBS containing $0.05 \%$ Tween 20 for 10 minutes and then incubated with horseradish peroxidase conjugated goat antirabbit antibodies. The proteins were detected by the enhanced chemiluminescence method (ECL), under the conditions recommended by the manufacturer (Amersham).

\section{RESULTS \\ Structure of the BamHI-H and BamHI-D fragments in the MDV T cell lines}

The T9 cells were serially maintained in culture and passaged for up to six months. Both low number (early T9) and high number passage stocks (late T9) were used in our study.

When PCR was performed with the pp38SI and pp38SD primer set a $1.0 \mathrm{~kb}$ DNA fragment was amplified from MSBl, T5, and early T9 DNA (not shown). No amplification was observed with late T9 and CEF DNA. Because BamHI-H and BamHI-D share the same sequence within $\mathrm{TR}_{\mathrm{L}}$ and $\mathrm{IR}_{\mathrm{L}}$, amplification of the pp24 gene fragment could be performed with pp38SI and the pp24SI primer specific for the $3^{\prime}$ proximal coding region of the pp24 gene (fig l). A $0.8 \mathrm{~kb}$ fragment was amplified from the DNA of all MDV cell lines (not shown). No amplification was observed for CEF DNA. 


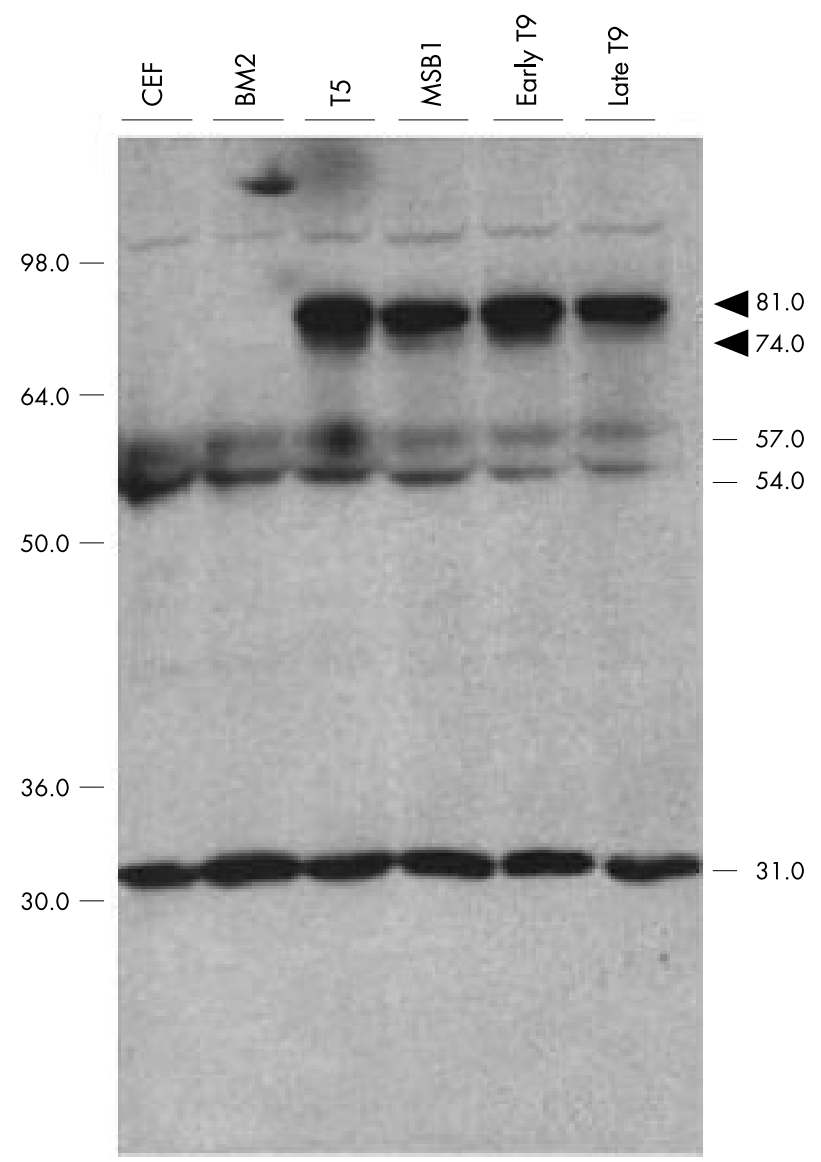

Figure 7 Analysis of the Eco-Q region encoding the meq gene. The expression of MEQ proteins in Marek's disease virus (MDV) transformed cell lines. Proteins $(100 \mu \mathrm{g})$ were denatured in Laemmli buffer and then resolved on $10 \%$ sodium dodecyl sulfate-polyacrylamide gel electrophoresis before transferring on to a PVDF membrane. The blot was probed with rabbit anti-MEQ polyclonal antibodies (1/3000 dilu$t_{i o n^{27}}$, followed by detection using the enhanced chemiluminescence (ECL) system (Amersham). Cell extracts from chicken embryo fibroblasts (CEFs) and BM2 were used as negative controls. Specific MDV products are indicated by arrows. Prestained molecular weight markers (Novex) are indicated in kilodaltons.

\begin{tabular}{|llll|}
\hline Table 1 & Induction of Marek's disease following injections of T5 and T9 cell lines \\
\hline Cellular strains & $\begin{array}{l}\text { Age at necroscopy } \\
\text { (weeks) }\end{array}$ & $\begin{array}{l}\text { Chickens with } \\
\text { macroscopic } \\
\text { lesions/injected ones (\%) }\end{array}$ & $\begin{array}{l}\text { Chickens with } \\
\text { macroscopic } \\
\text { lesions/contact ones (\%) }\end{array}$ \\
\hline T5 & 11 & $4 / 8(50)$ & $4 / 6(66)$ \\
Early T9 & $6-8$ & $8 / 9(88)$ & $5 / 6(83)$ \\
Late T9 & $6-13$ & $0 / 9(0)$ & $0 / 6(0)$ \\
\hline
\end{tabular}

Southern blot hybridisation performed with the BamHI fragment $\mathrm{H}$ as probe detected a $5.4 \mathrm{~kb}$ and a $12 \mathrm{~kb}$ BamHI fragment in early T9, T5, HPRS2, and MSB1 DNA, corresponding to the BamHI-H and BamHI-D fragments, respectively (fig $2){ }^{45}$ but not in the CEFs or in RP9 RAV transformed cells. The $5.4 \mathrm{~kb}$ BamHI-H fragment was not detected in late T9 cells, although the $12 \mathrm{~kb}$ fragment was still present, a result in agreement with amplification of the pp24 gene (fig 2, right hand panel). These results indicated that the BamHI-D fragment containing the pp24 gene was present in both early and late T9 cell DNA, and that the BamHI-H fragment is disrupted in the late $\mathrm{T} 9$ cells.

\section{Structure and expression of the region containing the ICP4 gene and LATs in the MDV cell lines}

The $\mathrm{IR}_{\mathrm{S}}$ contains the $5^{\prime}$ part of the BamHI fragment A, which encodes the immediate-early ICP4 gene. ${ }^{19}$ A specific fragment of the ICP4 gene obtained by PCR was used as a probe (fig 1).
Northern blotting using the ICP4 PCR product as a probe revealed that transcripts of 0.72 and $10.0 \mathrm{~kb}$ were expressed in MSB1, HPRS2, T5, and early T9 cell lines (fig 3). As previously reported, these RNA species resulted from antisense transcription of the ICP4 locus. ${ }^{21}{ }^{23}$ No ICP4 RNA species were detected from either late T9 cells or from cells that are not transformed by MDV (CEF, BM2, and RP9).

Hybridisation of EcoRI digested high molecular weight DNA with the ICP4 DNA probe detected a $5.8 \mathrm{~kb}$ DNA fragment in T5, MSB1, and early T9 cell lines (fig 4, left hand panel). No fragments were detected by this probe in late T9 cells DNA. In early T9 cells, this probe revealed an additional, but less intense band corresponding to a $6.8 \mathrm{~kb}$ DNA fragment. As expected from the previously published nucleotide sequence, ${ }^{19} 46$ the same probe detected a $2.3 \mathrm{~kb}$ fragment in the PvuII digested DNA from the T5, early T9, and MSBI cell lines (fig 4, right hand panel). 


\begin{tabular}{|c|c|c|c|c|}
\hline Cell lines & $\begin{array}{l}\text { No. } \\
\text { chickens }\end{array}$ & $\begin{array}{l}\text { Date of } \\
\text { sacrifice (or } \\
\text { death*) }\end{array}$ & Tumour localisation & Other disorders \\
\hline T5 inoculated chickens & $\begin{array}{l}955 \\
956 \\
957 \\
958 \\
959 \\
960 \\
961 \\
962\end{array}$ & $\begin{array}{l}11^{*} \\
11^{*} \\
7^{*} \\
11 \\
11 \\
11 \\
11 \\
11\end{array}$ & $\begin{array}{l}\text { (1) Heart } \\
\text { (0) } \\
\text { (ND) } \\
\text { (0) } \\
\text { (1) Liver nodes } \\
\text { (0) Ovary } \\
\text { (1) Ovary liver, rate, and eyes } \\
\text { (1) Ovary, lo }\end{array}$ & $\begin{array}{l}\text { Thymic and bursal atrophy } \\
\text { Normal } \\
\text { (ND) } \\
\text { Normal } \\
\text { Normal } \\
\text { Normal } \\
\text { Thymic, splenic, and bursal atrophy } \\
\text { Thymic and splenic atrophy }\end{array}$ \\
\hline T5 "contact" chickens & $\begin{array}{l}963 \\
964 \\
965 \\
966 \\
967 \\
968\end{array}$ & $\begin{array}{l}11 \\
11 \\
11 \\
10^{*} \\
11 \\
11\end{array}$ & $\begin{array}{l}\text { (1) Heart, lung, liver, and ovary } \\
\text { (1) Ovary } \\
\text { (1) Ovary, pancreas, liver, and oesophagus } \\
\text { (ND) } \\
\text { (1) Ovary } \\
\text { (0) }\end{array}$ & $\begin{array}{l}\text { Thymic, splenic, and bursal atrophy } \\
\text { Normal } \\
\text { (ND) } \\
\text { (ND) } \\
\text { (ND) } \\
\text { Normal }\end{array}$ \\
\hline $\begin{array}{l}\text { Early T9 inoculated } \\
\text { chickens }\end{array}$ & $\begin{array}{l}475 \\
476 \\
477 \\
478 \\
479 \\
480 \\
481 \\
482 \\
483\end{array}$ & $\begin{array}{l}6 \\
6 \\
6^{*} \\
6^{*} \\
8 \\
8 \\
8 \\
8 \\
6\end{array}$ & $\begin{array}{l}\text { (1) Testis, nerves } \\
\text { (1) Ovary, lung } \\
\text { (1) Kidney, liver } \\
\text { (1) Ovary } \\
\text { (1) Ovary } \\
\text { (1) Ovary } \\
\text { (1) Skin, nerves, and nodes in the gut } \\
\text { (1) Testis, muscle } \\
\text { (1) Testis }\end{array}$ & $\begin{array}{l}\text { Thymic, splenic, and bursal atrophy } \\
\text { Thymic, splenic, and bursal atrophy } \\
\text { Thymic and bursal atrophy } \\
\text { Thymic and bursal atrophy } \\
\text { (ND) } \\
\text { (ND) } \\
\text { (ND) } \\
\text { (ND) } \\
\text { (ND) }\end{array}$ \\
\hline $\begin{array}{l}\text { Early T9 "contact" } \\
\text { chickens }\end{array}$ & $\begin{array}{l}484 \\
485 \\
486 \\
487 \\
488 \\
489\end{array}$ & $\begin{array}{l}6^{*} \\
9^{*} \\
9^{*} \\
11^{*} \\
13^{*} \\
6^{*}\end{array}$ & $\begin{array}{l}\text { (ND) } \\
\text { (1) Lung, ovary } \\
\text { (1) Ovary } \\
\text { (1) Ovary } \\
\text { (1) Ovary } \\
\text { (1) Ovary }\end{array}$ & $\begin{array}{l}\text { (ND) } \\
\text { Thymic, splenic, and bursal atrophy } \\
\text { Thymic, splenic, and bursal atrophy } \\
\text { (ND) } \\
\text { (ND) } \\
\text { Thymic and bursal atrophy }\end{array}$ \\
\hline
\end{tabular}

(0) and (1) indicate the absence or presence of tumours, respectively. All inoculations were carried out by intraperitoneal injections of $10^{7}$ cells. ${ }^{\star}$ Chickens were sacrificed at the week indicated but in some cases they died before.

ND, none determined.

These results indicated that the 5' BamHI-A fragment containing the ICP4 gene is also disrupted in late T9 cells. As revealed by the detection of an additional $6.8 \mathrm{~kb}$ fragment, the 5' BamHI-A fragment is rearranged in early T9 cells. From the size of this fragment and the origin of the probe, the rearrangement in early T9 cells maps within the promoter of the ICP4 gene between the EcoRI and PvuII restriction sites (positions 11193 and 7750, respectively; numbering according to McKie and colleagues ${ }^{46}$ ).

\section{Expression of the meq gene in the MDV cell lines}

The Eco-Q fragment of the MDV genome encompasses the 3' end of the BamHI-I2 and BamHI-Q2 fragments. It contains an ORF referred to as meq. ${ }^{24}$

In MDV transformed cells, Southern blotting performed with the meq probe detected a $5.1 \mathrm{~kb}$ and a $1.3 \mathrm{~kb}$ EcoRI (fig 5, left hand panel) and a $2.7 \mathrm{~kb}$ BamHI fragment (fig 5, right hand panel), respectively. The sizes of these fragments were in agreement with the previously published nucleotide

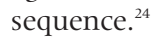

Wilson et al have reported that the reduced expression of MDV gC in attenuated strains did not result from structural alterations within or near that gene, and suggested that gene(s) encoding MDV regulatory protein(s) that interact with the MDV $\mathrm{gC}$ promoter might be altered during the attenuation process. ${ }^{47}$ The Eco-Q region expression pattern was established following northern blot hybridisation with the meq DNA probe. At least five transcripts with sizes ranging from 1.4, 1.8, 2.1, and 2.5 to $3.1 \mathrm{~kb}$ were detected in all the MDV cell lines (fig 6). Only minor differences in the degree of expression of these different species could be seen among RNA from these cell lines. This result was consistent with previous work reporting the expression of both spliced and unspliced sense transcripts in addition to antisense transcripts from the BamHI-I2/Q2 region encoding MEQ. ${ }^{24}$ 48-50

Immunoblotting performed with a polyclonal MEQ antibody ${ }^{27}$ revealed proteins of 31,54 , and $57 \mathrm{kDa}$ in all cell extracts (fig 7). An additional 74-80 kDa doublet was specifically detected in MSB1, T5, and the early and late T9 cell extracts. The apparent molecular weight of these MEQ proteins was higher than those described previously. ${ }^{24}{ }^{50}$ Liu and colleagues ${ }^{27}$ reported that the MEQ protein migrated with an apparent molecular weight ranging from 50 to $75 \mathrm{kDa}$, depending upon the origin of the cell lines analysed. These discrepancies may result from post-translational modifications, such as phosphorylation. Alternatively spliced MEQ RNA species also contribute to the variation in apparent sizes of the MEQ proteins. ${ }^{49}$

\section{Pathogenicity of the MDV cell lines in vivo}

Marek's disease can be experimentally induced by the injection of MDV lymphoblastoid cell lines into susceptible birds. To determine whether early and late T9 cells were still able to induce Marek's disease, $10^{7}$ cells were injected intraperitoneally into 1 day old chickens. The T5 cell line was used as a positive control.

Chickens injected with either T5 or early T9 cells developed classic signs of Marek's disease (paralysis; table 1). Furthermore, contact exposed chickens developed signs of Marek's disease, therefore confirming the horizontal transmission of infectious virus. Necropsy frequently revealed macroscopic tumours and bursal and thymic atrophy in either inoculated or contact exposed chickens. Lymphoid tumours were localised mainly to the sexual organs, but occasionally arose in liver, kidney, heart, and proventriculis (table 2). The sexual localisation appeared to be a characteristic of the oncogenic HPRS16 


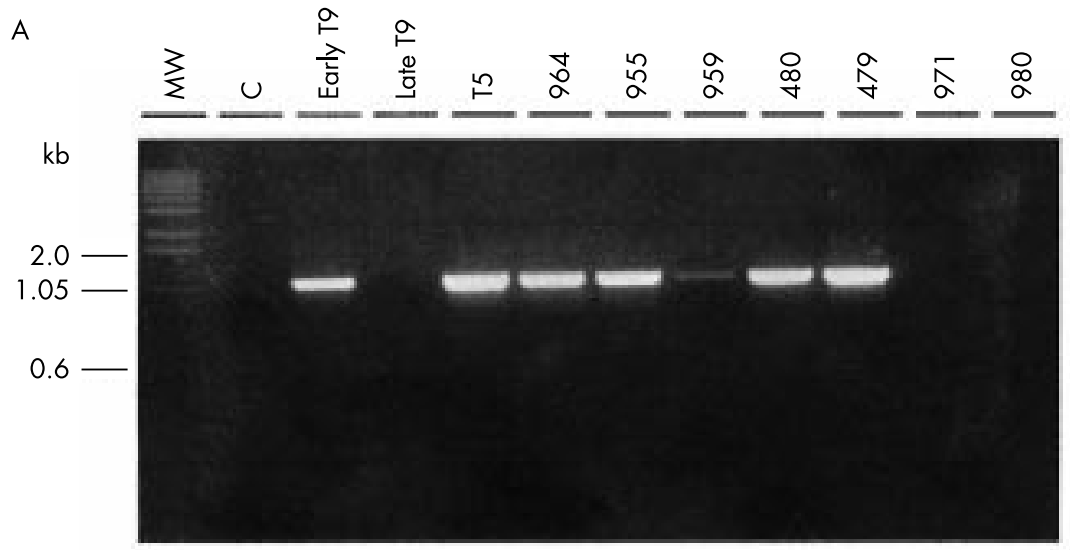

B
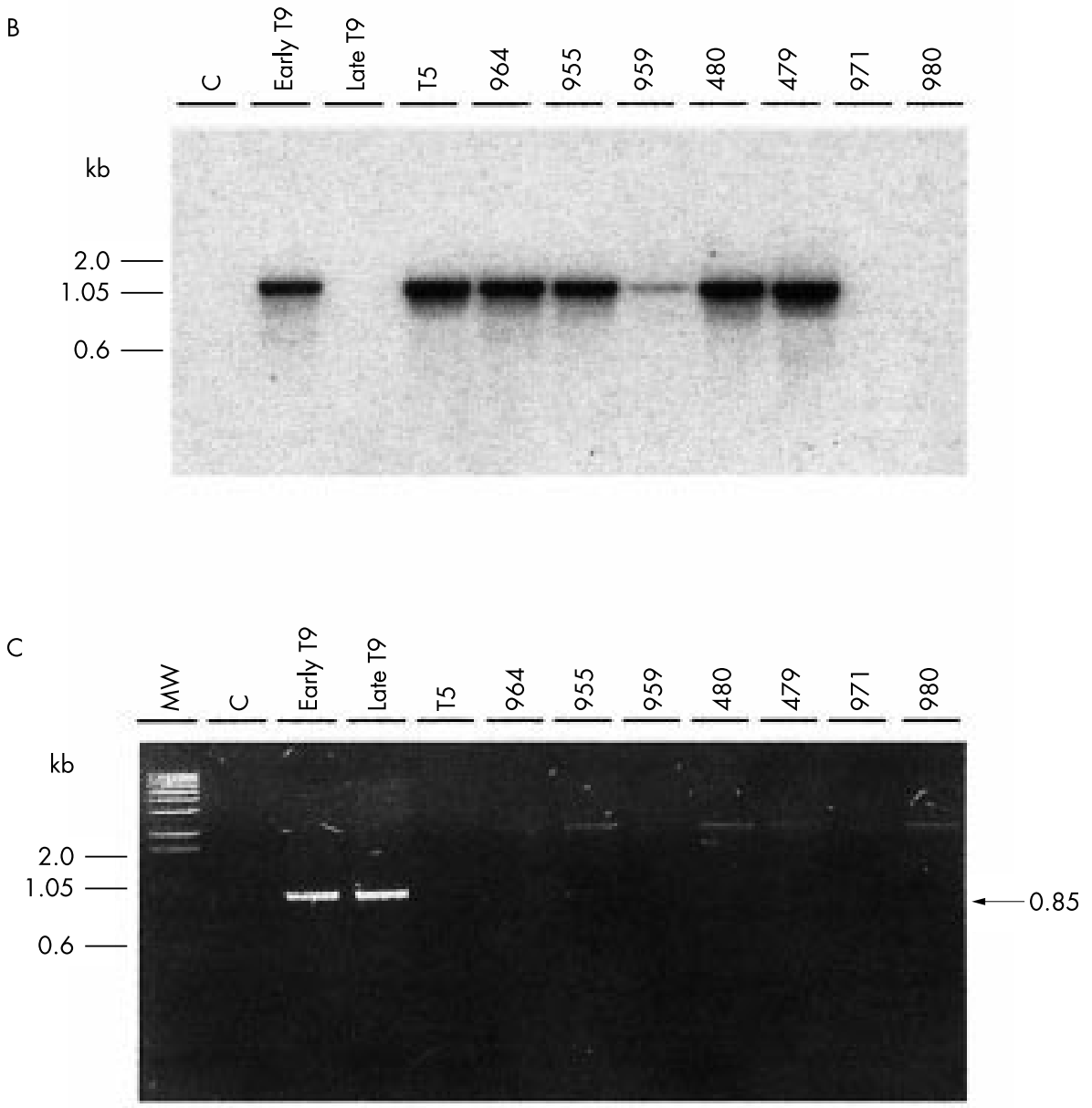

Figure 8 Molecular analysis of the tumours (or normal tissues) isolated from T5, early T9, and late T9 cell line inoculated and contact chickens. (A) Detection of Marek's disease virus (MDV) sequences in DNA from induced tumours. PCR amplification was carried out on DNA isolated from different tissues of chickens injected with T5 (964, 955, and 959), early T9 (479 and 480), and late T9 (971 and 980). The control without DNA template (lane C) was performed under identical conditions. Additional controls included DNA isolated from the early T9, late T9, and T5 cell lines. PCR products were run on a $1.5 \%$ agarose gel and visualised with an ultraviolet transilluminator. The positions of selected bands from a $1 \mathrm{~kb}$ ladder marker (BRL) are indicated on the left. (B) PCR products run on the gel were transferred on to a nitrocellulose membrane and then hybridised with [ $\left.{ }^{32} \mathrm{P}\right]$ labelled oligonucleotides pp38I. (C) PCR amplification of the 5' RAV-c-myb junction. The same DNA templates as in (A) were subjected to 30 rounds of amplification using primer 1 (corresponding to c-myb exon 3 sequences) and primer 2 (corresponding to RAV gag sequences). ${ }^{32}$ PCR products were run on a $1.5 \%$ agarose gel and visualised by means of an ultraviolet transilluminator. The position of the PCR amplified 850 bp 5' junction fragment is indicated. Control experiments were performed under identical conditions without DNA (lane C). 
strain of $\mathrm{MDV}^{51}$ Histological examination revealed lymphocytic infiltration of peripheral nerves in all the chickens examined (four of four for the early T9 cells and 11 of 11 for the T5 cells induced Marek's disease; data not shown).

In contrast, birds inoculated with late T9 cells or contact exposed chickens developed no signs of Marek's disease (table 1). Chickens were sacrificed at 15 weeks. Necropsy revealed no signs of bursal or thymic atrophy, splenomegaly, or tumour formation. Histological examination of peripheral nerves confirmed the absence of Marek's disease lesions (data not shown).

To confirm that injected birds indeed carried MDV genomes, total cellular DNA isolated from tumours was used as template for PCR amplification. Consistent with the presence of MDV DNA sequences, a $1.0 \mathrm{~kb}$ product was amplified with a primer set for the pp38 gene (fig l) using DNA isolated from spleen, liver, and ovary of chickens injected with early T9 and T5 cell lines (fig 8A). A $1.0 \mathrm{~kb}$ product was also amplified from a contact chicken, indicating that inoculated chickens produced viruses that could infect neighbouring chickens. No amplification product was obtained with DNA from late T9 cell injected chickens (fig 8A). The origin of the amplified product was confirmed by probing with the pp38I labelled oligonucleotide (fig 8B).

To establish whether tumours arising in T9 infected birds originate from an expansion of the injected tumour cells or from MDV induced transformation, we took advantage of the previously reported activation of c-myb in T9 cells s $^{32}$ and performed MHC typing. Using primers specific for the $5^{\prime}$ mybRAV junction in T9 cells ${ }^{32}$ no products were amplified from DNA derived from either early T9 induced tumours or tissues from late T9 inoculated chickens (fig 8C). Positive and negative controls were performed with late and early T9 and T5 cells, respectively. PCR-single stranded conformational polymorphism experiments performed with different sets of primers specific for the YF gene from the MHC class I established that tumoral cells exhibited the same pattern as that of the recipient chicken. This pattern was different from that of T5, early T9, and late T9 cells (data not shown). These results indicated that tumour formation in injected animals did not result from the proliferation of early T9 or T5 cells, but from the transformation of chicken recipient lymphoid cells by MDV.

\section{DISCUSSION}

We have previously reported that the MDV transformed T9 lymphoblastoid cell line contained a RAV insertional activation of c-myb and a rearranged MDV genome lacking the BamHI-H fragment. To establish the relative participation of the MDV and myb sequences in the transformed phenotype of the T9 cells, we analysed them for the presence of MDV oncogenic sequences. We have focused our analysis on the following potential oncogenic regions: the BamHI-H, BamHI-A, and ECo-Q fragments, which encode the pp38 and the $1.8 \mathrm{~kb}$ RNA family; the ICP4 homologue transcriptional factor; and meq. ${ }^{52-54}$ Genomic analysis revealed that all these fragments were apparently intact in the early $\mathrm{T} 9$ cells and expression patterns from these regions were identical to those from the MSBl prototype cell line and T5 cells, which express infectious transforming MDV. Conversely, the BamHI-H fragment and the ICP4 coding region were rearranged in the late T9 cells. In vivo experiments confirmed that these alterations abrogated the capacity of the late T9 cell line to induce Marek's disease in chickens.

The loss of the BamHI-H fragment in late T9 cells is reminiscent of the situation encountered in attenuated strains obtained after serial passage of virulent MDV strains in primary CEF. ${ }^{79}$ Because no alteration of this region occurred upon repeated passages of the early T9 cells (not shown), the rearrangement of this region in late $\mathrm{T} 9$ cells must have involved another mechanism. Moreover, an additional, less intense fragment was revealed with the ICP4 probe in the early $\mathrm{T} 9$ cells that could result from rearrangement in progress in a subpopulation of cells. Hayashi and colleagues ${ }^{55}$ have previously described an amplification of a 178 bp repeat sequence within the $1.6 \mathrm{~kb}$ HindIII subfragment of BamHI-A in viral DNA isolated from both pathogenic and non-pathogenic strains, and in established lymphoblastic cells. In this last case, the 178 bp expansions mapped about $1 \mathrm{~kb}$ downstream of the stop codon of the ICP4 gene, giving rise to heterogeneity of $\mathrm{IR}_{\mathrm{S}}$ and $\mathrm{TR}_{\mathrm{s}}$. In contrast, alteration in early $\mathrm{T} 9$ cells seems to take place in the ICP4 promoter region without revealing heterogeneity accounted for expansions. The expression of ICP4 is down regulated by the LATs during latency and the balance between the sense (ICP4) and antisense transcripts may serve as a switch to turn off MDV replication during latency. ${ }^{20}$ The lack of the ICP4 and LAT coding regions in the late T9 cell line may totally abrogate reactivation of the virus. Because an ori sequence is found in the bidirectional promoter of pp38 and the $1.8 \mathrm{~kb}$ family RNA gene (BamHI-H), it is likely that in the late T9 cells MDV is unable to replicate. ${ }^{56-58}$ Indeed, immunodiffusion performed with blood samples from chickens inoculated with late T9 cells did not reveal antibody against MDV (data not shown), confirming the fact that late T9 cells did not produce infectious viruses and were no longer capable of inducing Marek's disease.

\section{"Because MEQ was the only MDV oncogene fully expressed in the late T9 cells, our results raise questions regarding the factors involved in the maintenance of the transformed phenotype in these cells"}

Deletions and expansions of tandem repeats were reported to occur concurrently with attenuation of oncogenic MDV strains upon extensive passages in primary CEFs. ${ }^{745960}$ Usually, MDV lymphoblastoid cells are immortalised cell lines, which are latently infected with $\mathrm{MDV}^{61}{ }^{62}$ and capable of transferring MDV to CEFs or duck embryo fibroblasts in vitro. Despite many years in culture, these cell lines are still able to induce Marek's disease in susceptible birds. Repeatedly passaged T9 cells might have selected cells containing deletion of the BamHI-H and the ICP4 encoding region in their MDV genome and other gross structural alterations that were not detected in our study. The relative instability of the MDV genome in these cells could result from insertion and excision events mediated by RAV-1 and homologous recombination between long terminal repeat sequences because it has been reported that the MDV genome often undergoes structural changes, including insertions of retroviral elements. ${ }^{43-66}$ Identification and sequencing of junction sites at the border of these deletions could help in elucidating the mechanism involved in the disruption of the MDV sequences in late T9 cells.

Because MEQ was the only MDV oncogene fully expressed in the late T9 cells, our results raise questions regarding the factors involved in the maintenance of the transformed phenotype in these cells. We have previously shown that T9 cells expressed high amounts of a truncated MYB protein as a result of RAV-1 integration within the c-myb allele. ${ }^{32} \mathrm{~A}$ similar truncation conferred a transforming potential on myb, when assessed in primary chicken fibroblasts, ${ }^{67}$ and related chimaeric mRNA was isolated from $\mathrm{B}$ lymphomas and fibrosarcomas induced by avian leukosis virus. ${ }^{68}$ To our knowledge, this is the only report of a RAV insertional activation of c-myb in a T lymphoma. Liu et al reported that MEQ can transform established Rat-2 fibroblasts but MEQ alone is not capable of transforming primary cells. $^{27}$ Furthermore, recombinant retroviruses carrying meq yield a low incidence of sarcomas, indicating that meq is a weak oncogene ${ }^{27}$ and that meq may require additional cooperating oncogenes to display its full transforming activity. At least four MDV genes (pp38, ICP4, meq, and the $1.8 \mathrm{~kb}$ RNA family) have been shown to be important for the maintenance of the transformed phenotype 


\section{Take home messages}

- Longterm culture of a Marek's disease virus (MDV transformed cell line (late T9) containing a RAV insertiona activation of the c-myb protooncogene led to the disruption of the MDV BamHI-H and BamHI-A oncogenic regions and $M E Q$ was the only detected $M D V$ oncoprotein in these cells

- In late T9 cells, it is possible that the truncated MYB protein compensates for the loss of MDV oncoproteins

- In addition, it is possible that the maintenance of transformation in this cell line may require $M E Q$ and $M Y B$

in MSBl cells. ${ }^{18}$ Because meq expression is detected in late T9 cells, we speculate that the activation of c-myb might compensate for the lack of MDV genes and act synergistically with meq to maintain the transformed phenotype in late T9 cells.

To determine whether the expression of both the MEQ and truncated MYB proteins is required for the maintenance of the transformed phenotype, we have engineered T9 cells that express antisense mRNA using the pMDL7 inducible vector (pMD221 for meq antisense ${ }^{18}$ and pMDmyb, our construct). In contrast to Morgan's laboratory, we failed to establish antisense expressing cell lines, but we were able to establish control cell lines (expressing sense myb and meq). These results suggested that the inhibition of meq or myb expression might interfere with T9 cell proliferation; an observation in favour of a role for both the MYB and MEQ oncoproteins in the maintenance of the transformed phenotype. Another antisense strategy should be explored to determine the subtle contribution of activated myb and/or meq in this phenotype. Nonetheless, our results indicate that T9 cells constitute a cellular model to identify the meq target genes in the context of cells carrying a defective MDV genome.

\section{ACKNOWLEDGEMENTS}

We are grateful to Dr F Colbere-Garapin for critical reading of the manuscript. The pBamHI-H used in this study was kindly provided by Dr N Ross and the anti-MEQ polyclonal antibody by H-J Kung and L Lee. We thank Dr J-L Liu for helpful comments about western blotting and Dr R Morgan for providing the pMD vectors. Part of this study was performed when the "Laboratoire d'Oncologie Virale et Moléculaire" was affiliated to the CNRS-UMR146 at the Institut Curie. This research was funded by grants to BP from Association pour la Recherche contre le Cancer (ARC), Ligue Nationale Contre le Cancer (LNCC), and Fondation de France. ELR was supported by a fellowship from Société Française d'Hématologie.

\section{Authors' affiliations}

E Le Rouzic, B Perbal, Laboratoire d'Oncologie Virale et Moléculaire, UFR de Biochimie, Université Paris 7-D. Diderot, Paris, France P Thoraval, M Afanassieff, G Dambrine, INRA Tours, Station de Pathologie Aviaire et Parasitologie, 37380 Nouzilly, France Y Cherel, Ecole Nationale Vétérinaire, INRA UR703, 44307 Nantes, Cedex 03, France

\section{REFERENCES}

1 Biggs PM. The Leeuwenhoek Lecture. Marek's disease herpesvirus: oncogenesis and prevention. Philos Trans R Soc Lond B Biol Sci 1997; 352:1951-62

2 Fukuchi K, Sudo M, Lee Y, et al. Structure of Marek's disease virus DNA: detailed restriction enzyme map. J Virol 1984;51:102-9.

3 Tulman ER, Afonso CL, Lu Z, et al. The genome of a very virulent Marek's disease virus. J Virol 2000;74:7980-8.

4 Lee LF, Wu P, Sui D, et al. The complete unique long sequence and the overall genomic organization of the GA strain of Marek's disease virus. Proc Natl Acad Sci U S A 2000;97:6091-6.

5 Ross NL. T-cell transformation by Marek's disease virus. Trends Microbiol 1999:7:22-9.

6 Churchill AE, Chubb RC, Baxendale W. The attenuation with loss of oncogenicity of the herpes-type virus of Marek's disease virus (strain HPRS-16) on passage in cell culture. J Gen Virol 1969:4:557-564.

7 Fukuchi K, Tanaka A, Schierman LW, et al. The structure of Marek disease virus DNA: the presence of unique expansion in nonpathogenic viral DNA. Proc Natl Acad Sci U S A 1985;82:751-4.
8 Silva RF, Witter RL. Genomic expansion of Marek's disease virus DNA is associated with serial in vitro passage. J Virol 1985;54:690-6.

9 Maotani K, Kanamori A, Ikuta K, et al. Amplification of a tandem direct repeat within inverted repeats of Marek's disease virus DNA during seria in vitro passage. J Virol 1986;58:657-60

10 Ross N, Binns MM, Sanderson M, et al. Alterations in DNA sequence and RNA transcription of the Bam $\mathrm{HI}-\mathrm{H}$ fragment accompany attenuation of oncogenic Marek's disease herpesvirus. Virus Genes 1993;7:33-51.

11 Bradley G, Lancz G, Tanaka A, et al. Loss of Marek's disease virus tumorigenicity is associated with truncation of RNAs transcribed within BamHI-H. J Virol 1989:63:4129-35.

12 Kawamura $M$, Hayashi $M$, Furuichi $T$, et al. The inhibitory effects of oligonucleotides, complementary to Marek's disease virus mRNA transcribed from the BamHI-H region, on the proliferation of transformed lymphoblastoid cells, MDCC-MSB 1. J Gen Virol 1991;72:1105-11.

13 Peng F, Donovan J, Specter S, et al. Prolonged proliferation of primary chicken embryo fibroblasts transfected with cDNAs from the BamHI-H gene family of Marek's disease virus. Int J Oncol 1993;3:85-94.

14 Peng F, Specter S, Tanaka A, et al. A 7 kDa protein encoded by the BamHI-H gene family of Marek's disease virus is produced in lytically and latently infected cells. Int J Oncol 1994;4:799-802.

15 Hong Y, Coussens PM. Identification of an immediate-early gene in the Marek's disease virus long internal repeat region which encodes a unique 14-kilodalton polypeptide. J Virol 1994;68:3593-603.

16 Zhu GS, Iwata A, Gong M, et al. Marek's disease virus type 1-specific phosphorylated proteins pp38 and pp24 with common amino acid termini are encoded from the opposite junction regions between the long unique and inverted repeat sequences of viral genome. Virology 1994;200:816-20

17 Chen X, Velicer LF. Expression of the Marek's disease virus homolog of herpes simplex virus glycoprotein B in Escherichia coli and its identification as B antigen. J Virol 1992;66:4390-8.

18 Xie Q, Anderson AS, Morgan RW. Marek's disease virus (MDV) ICP4 pp38, and meq genes are involved in the maintenance of transformation of MDCC-MSB 1 MDV-transformed lymphoblastoid cells. J Virol 1996;70: $1125-31$

19 Anderson AS, Francesconi A, Morgan RW. Complete nucleotide sequence of the Marek's disease virus ICP4 gene. Virology 1992;189:657-67.

20 Abujoub AA, Coussens PM. Evidence that Marek's disease virus exists in a latent state in a sustainable fibroblast cell line. Virology 1997:229:309-21.

21 Cantello JL, Anderson AS, Morgan RW. Identification of latency-associated transcripts that map antisense to the ICP4 homolog gene of Marek's disease virus. J Virol 1994;68:6280-90.

22 Cantello JL, Parcells MS, Anderson AS, et al. Marek's disease virus latency-associated transcripts belong to a family of spliced RNAs that are antisense to the ICP4 homolog gene. J Virol 1997;71:1353-61.

23 Li DS, Pastorek J, Zelnik V et al. Identification of novel transcripts complementary to the Marek's disease virus homologue of the ICP4 gene of herpes simplex virus. J Gen Virol 1994;75:1713-22.

24 Jones D, Lee L, Liu JL, et al. Marek disease virus encodes a basic-leucine zipper gene resembling the fos/jun oncogenes that is highly expressed in ymphoblastoid tumors [published erratum appears in Proc Natl Acad Sci U S A 1993;90:2556]. Proc Natl Acad Sci U S A 1992;89:4042-6.

25 Liu JL, Lee LF, Ye Y, et al. Nucleolar and nuclear localization properties of a herpesvirus bZIP oncoprotein, MEQ. J Virol 1997;71:3188-96.

26 Ross N, O'Sullivan G, Rothwell C, et al. Marek's disease virus EcoRI-Q gene (meq) and a small RNA antisense to ICP4 are abundantly expressed in CD4+ cells and cells carrying a novel lymphoid marker, AV37, in Marek's disease lymphomas. J Gen Virol 1997;78:2191-8.

27 Liu JL, Ye Y, Lee LF, et al. Transforming potential of the herpesvirus oncoprotein MEQ: morphological transformation, serum-independent growth, and inhibition of apoptosis. J Virol 1998;72:388-95.

28 Liu JL, Ye Y, Qian Z, et al. Functional interactions between herpesvirus oncoprotein MEQ and cell cycle regulator CDK2. J Virol 999;73:4208-19.

29 Qian Z, Brunovskis P, Rauscher F, 3rd, et al. Transactivation activity of Meq, a Marek's disease herpesvirus bZIP protein persistently expressed in latently infected transformed T cells. J Virol 1995:69:4037-44.

30 Qian Z, Brunovskis $P$, Lee L, et al. Novel DNA binding specificities of a putative herpesvirus bZIP oncoprotein. J Virol 1996;70:7161-70.

31 Pratt WD, Cantello J, Morgan RW, et al. Enhanced expression of the Marek's disease virus-specific phosphoproteins after stable transfection of MSB-1 cells with the Marek's disease virus homologue of ICP4. Virology 1994;201:132-6.

32 Le Rouzic E, Perbal B. Retroviral insertional activation of the c-myb proto-oncogene in a Marek's disease T-lymphoma cell line. J Virol 1996;70:7414-23

33 Mazzella O, Cauchy L, Coudert F, et al. Chicken thymocyte-specific antigens identified by monoclonal antibodies: characterization and distribution in normal tissues and in tumoral tissues from Marek's disease chicken. Hybridoma 1986;5:319-28.

34 Quéré P, Dambrine G. Development of anti-tumoral cell-mediated cytotoxicity during the course of Marek's disease in chickens. Ann Rech Vet 1988;19:193-201.

35 Akiyama Y, Kato S. Two cell lines from lymphomas of Marek's disease. Biken J 1974;17:105-16.

36 Powell PC, Payne LN, Frazier JA, et al. T lymphoblastoid cell lines from Marek's disease lymphomas. Nature 1974.251:79-80.

37 Okazaki W, Witter RL, Romero R, et al. Induction of lymphoblastoid leukosis transplantable tumors and the establishment of lymphoblastoid cell lines. Avian Pathol 1980;9:311-29. 
38 Moscovici C, Zeller N, Moscovici G. Continuous lines of AMV-transformed non-producer cells: growth and oncogenic potential in the chick embryo. In: Revoltella RF, Pontieri GM, Basilico C, et al, eds. Expression of differentiated functions in cancer cells. New York: Raven Press, 1982:435-49.

39 Soret J, Kryceve-Martinerie C, Crochet J, et al. Transformation of brown leghorn chicken embryo fibroblasts by avian myeloblastosis virus proviral DNA. J Virol 1985;55:193-205

40 Bacon LD, Schierman LW, McBride RA. Alloimmune hemolytic plaque-forming cells: kinetics of $\lg M$ and $\lg G$ alloantibody releasing cells during a primary and secondary immune response of chickens. J Immunol 1972;109:207-16.

41 Perbal B. A practical guide to molecular cloning, 2nd ed. New York: John Wiley \& Sons, 1988.

42 Bregni $M$, Magni $M$, Siena $S$, et al. Human peripheral blood hematopoietic progenitors are optimal targets of retroviral-mediated gene transfer. Blood 1992;80:1418-22.

43 Banders UT, Coussens PM. Interactions between Marek's disease virus encoded or induced factors and the Rous sarcoma virus long terminal repeat promoter. Virology 1994;199:1-10.

44 Mac Leod AR. Expression of the mRNA coding for glyceraldehyde-3-phosphate dehydrogenase. Eur J Biochem 1981;119:353-8.

45 Ross LJ, Binns MM, Tyers P, et al. Construction and properties of a turkey herpesvirus recombinant expressing the Marek's disease virus homologue of glycoprotein B of herpes simplex virus. J Gen Virol 1993;74:371-7.

46 McKie EA, Ubukata E, Hasegawa S, et al. The transcripts from the sequences flanking the short component of Marek's disease virus during latent infection form a unique family of 3 '-coterminal RNAs. J Virol 1995;69:1310-14

47 Wilson MR, Southwick RA, Pulaski JT, et al. Molecular analysis of the glycoprotein C-negative phenotype of attenuated Marek's disease virus. Virology 1994;199:393-402.

48 Peng Q, Shirazi Y. Isolation and characterization of Marek's disease virus (MDV) cDNAs from a MDV-transformed lymphoblastoid cell line: identification of an open reading frame antisense to the MDV Eco-Q protein (Meq). Virology 1996;221:368-74

49 Peng Q, Shirazi Y. Characterization of the protein product encoded by a splicing variant of the Marek's disease virus Eco-Q gene (Meq). Virology 1996;226:77-82.

50 Peng Q, Zeng $M$, Bhuiyan ZA, et al. Isolation and characterization of Marek's disease virus (MDV) cDNAs mapping to the BamHI-I2, BamHI-Q2, and BamHI-L fragments of the MDV genome from lymphoblastoid cells transformed and persistently infected with MDV Virology 1995;213:590-9

51 Purchase HG, Biggs PM. Characterization of five isolates of Marek's disease. Res Vet Sci 1967;8:440-9.

52 Kung HJ, Tanaka A, Nonoyama M. Two gene families of Marek's disease virus (MDV) with a potential role in tumor induction in chicken. Int J Oncol 1995;6:997-1002
53 Venugopal K. Marek's disease: an update on oncogenic mechanisms and control. Res Vet Sci 2000;69:17-23

54 Kung HJ, Xia L, Brunovskis P, et al. Meq: an MDV-specific bZIP transactivator with transforming properties. Curr Top Microbiol Immunol 2001;255:245-60.

55 Hayashi M, Jessip J, Fukuchi K, et al. The structure of Marek's disease virus DNA: amplification of repeat sequence in IRs and TRs. Microbiol Immunol 1988;32:265-74.

56 Bradley G, Hayashi M, Lancz G, et al. Structure of the Marek's disease virus BamHI-H gene family: genes of putative importance for tumor induction. J Virol 1989;63:2534-42.

57 Katsumata A, Iwata A, Ueda S. Cis-acting elements in the lytic origin of DNA replication of Marek's disease virus type 1. J Gen Virol 1998:79:3015-18.

58 Morgan RW, Cantello JL, Claessens JA, et al. Inhibition of Marek's disease virus DNA transfection by a sequence containing an alphaherpesvirus origin of replication and flanking transcriptional regulatory elements. Avian Dis 1991;35:70-81.

59 van Iddekinge BJ, Stenzler L, Schat KA, et al. Genome analysis of Marek's disease virus strain CVI-988: effect of cell culture passage on the inverted repeat regions. Avian Dis 1999;43:182-8.

60 Wilson MR, Coussens PM. Purification and characterization of infectious Marek's disease virus genomes using pulsed field electrophoresis. Virology 1991;185:673-80.

61 Delecluse HJ, Schuller S, Hammerschmidt W. Latent Marek's disease virus can be activated from its chromosomally integrated state in herpesvirus-transformed lymphoma cells. EMBO J 1993:12:3277-86.

62 Delecluse HJ, Hammerschmidt W. Status of Marek's disease virus in established lymphoma cell lines: herpesvirus integration is common. J Virol 1993;67:82-92

63 Isfort RJ, Qian Z, Jones D, et al. Integration of multiple chicken retroviruses into multiple chicken herpesviruses: herpesviral $\mathrm{gD}$ as a common target of integration. Virology 1994;203:125-33.

64 Isfort $\mathbf{R}$, Jones $D$, Kost $R$, et al. Retrovirus insertion into herpesvirus in vitro and in vivo. Proc Natl Acad Sci U S A 1992;89:991-5.

65 Witter RL, Li D, Jones D, et al. Retroviral insertional mutagenesis of a herpesvirus: a Marek's disease virus mutant attenuated for oncogenicity but not for immunosuppression or in vivo replication. Avian Dis 1997;41:407-21.

66 Sakaguchi M, Sonoda K, Matsuo K, et al. Insertion of tandem direct repeats consisting of avian leukosis virus LTR sequences into the inverted repeat region of Marek's disease virus type 1 DNA. Virus Genes 1997; 14:157-62

67 Dini PW, Lipsick JS. Oncogenic truncation of the first repeat of c-Myb decreases DNA binding in vitro and in vivo. Mol Cell Biol 1993; 13:7334-48.

68 Press RD, Kim A, Ewert DL, et al. Transformation of chicken myelomonocytic cells by a retrovirus expressing the $\mathrm{v}$-myb oncogene from the long terminal repeats of avian myeloblastosis virus but not Rous sarcoma virus. J Virol 1992;66:5373-83.

\section{CORRECTION}

Paroxysmal nocturnal haemoglobulinuria: Nature's gene therapy? R J Johnson, P Hillmen Mol Pathol 2002; 55: 145-52.

The authors' affiliations were missing from the above paper. They are as follows: R J Johnson, Department of Haematology, Birmingham Heartlands Hospital, Bordesley Green East, Birmingham B9 5SS, UK; P Hillmen, Haematological Malignancy Diagnostic Service, the General Infirmary at Leeds, Great George Street, Leeds LSI 3EX, UK. 